\title{
Middle Triassic evaporite sedimentation in the Catalan basin: Implications for the paleogeographic evolution in the NE Iberian platform
}

F. Orti

f.orti@ub.edu

J.M. Salvany

josepm.salvany@upc.edu

L. Rosell ${ }^{\mathrm{a}, *}$

lrosell@ub.edu

X. Castelltort

M. Inglès

m.ingles@ub.edu

E. Playà ${ }^{a}$

e.playa@ub.edu

a Departament de Mineralogia, Petrologia i Geologia Aplicada, Facultat de Ciències de la Terra, Universitat de Barcelona, C/ Martí i Franquès, s/n, 08028 Barcelona, Spain

bepartament d"'Enginyeria Civil i Ambiental, Universitat Politècnica de Catalunya, C/ Jordi Girona, 1-3, 08034 Barcelona, Spain

'Departament de Medi Ambient i Ciències del Sòl, Universitat de Lleida, C/ Av. Alcalde Rovira i Roure 191, 25198 Lleida, Spain

${ }^{*}$ Corresponding author.

Editor: Dr. B. Jones

Abstract

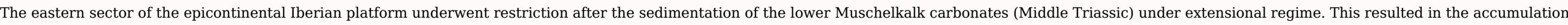

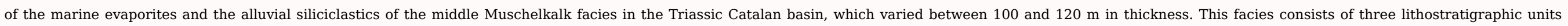

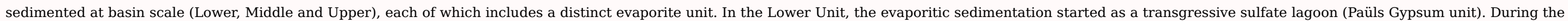

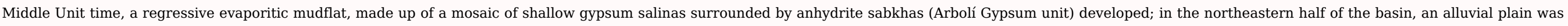

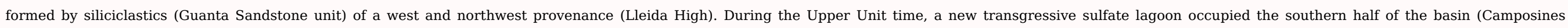

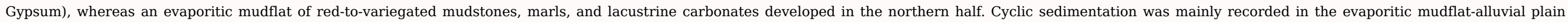

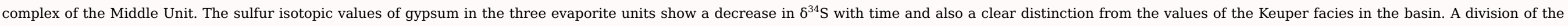

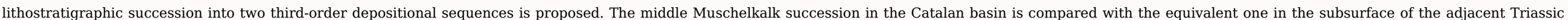
Maestrat basin, which was filled with $>600 \mathrm{~m}$ of marine evaporites.

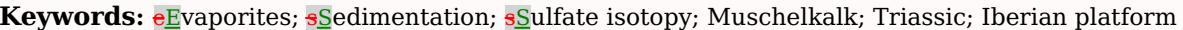

\subsection{Introduction}




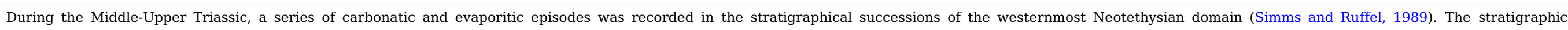

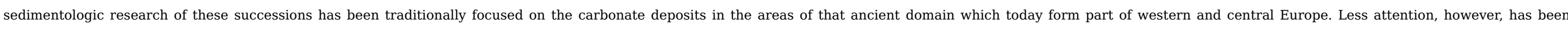
dedicated to the study of the associated evaporites despite the fact that they would yield insight into the paleogeographic evolution of the domain.

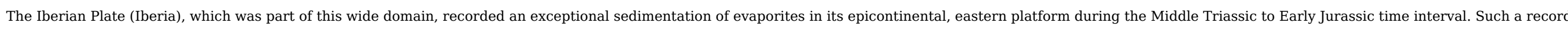

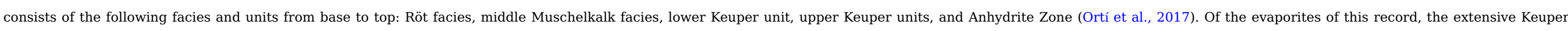

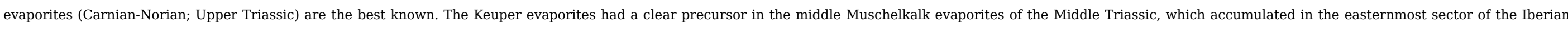

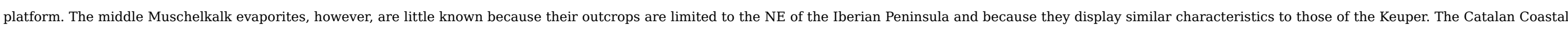
Ranges, where many outcrops of these evaporites occur, were selected for the present study. These outcrops correspond to the ancient Triassic Catalan basin.

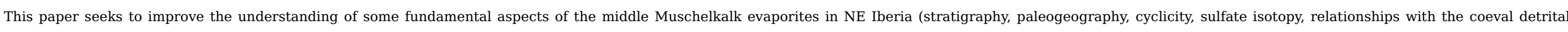

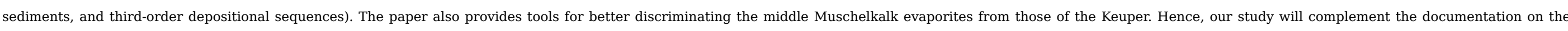

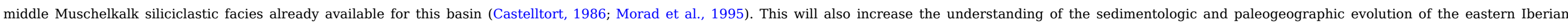
platform during the Middle Triassic time.

\subsection{Geological setting}

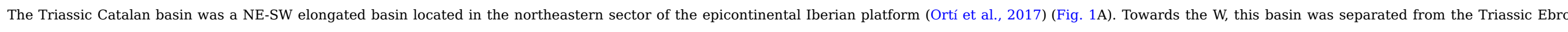

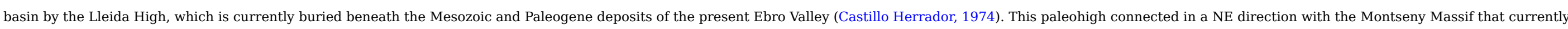

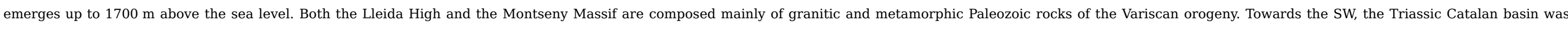

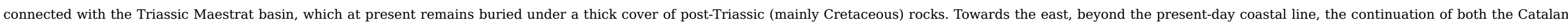
and the Maestrat basins underneath the Mediteraneanmediterranean Sea is poorly documented.

(A)

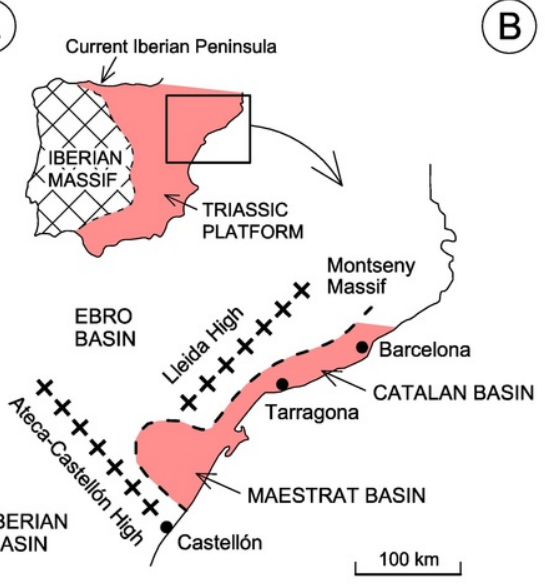

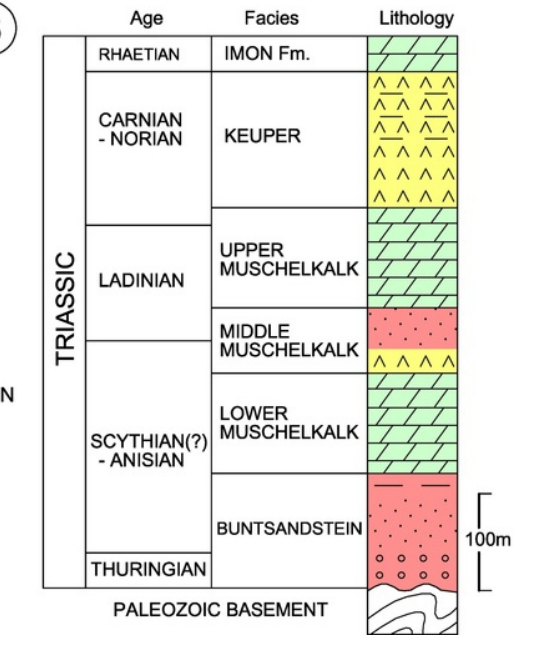

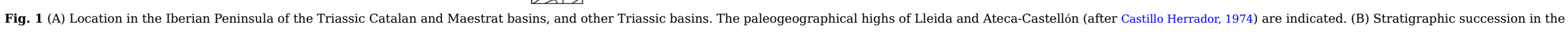
Triassic Catalan basin (age of the facies taken from Calvet and Marzo, 1994, fig. 14).

alt-text: Fig. 1

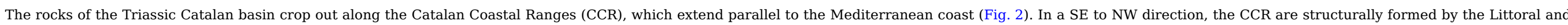




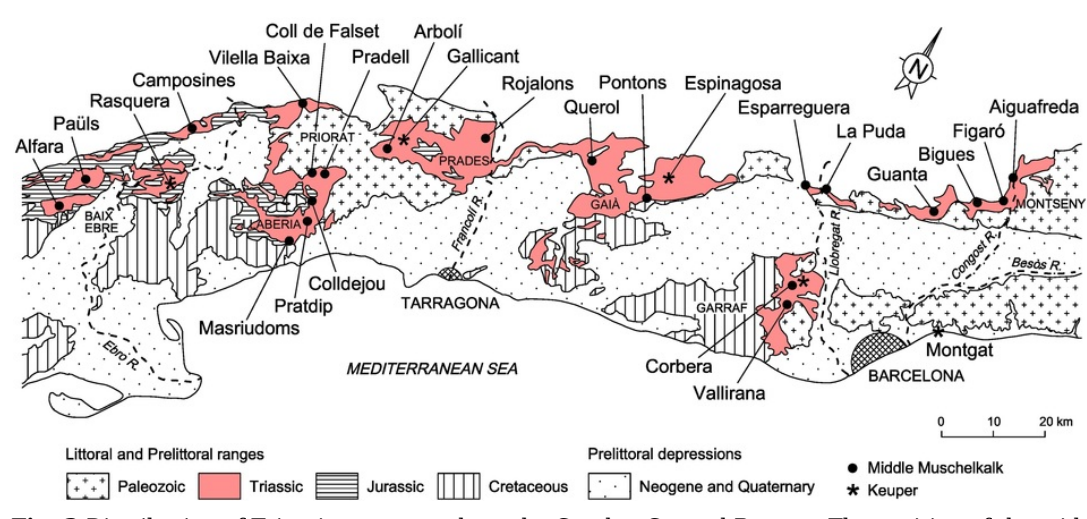

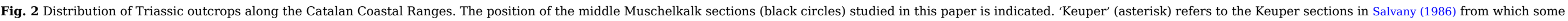
gypsum samples were analysed isotopically for the present paper.

\section{alt-text: Fig. 2}

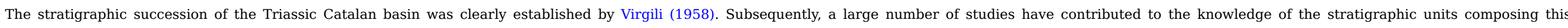

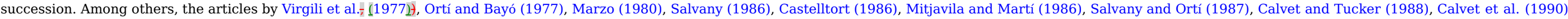

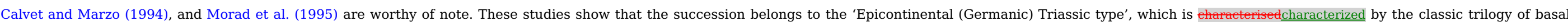

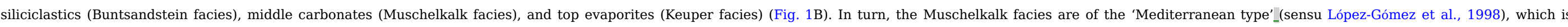

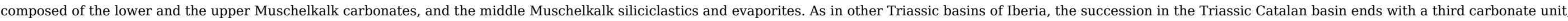
the Imón Fm.

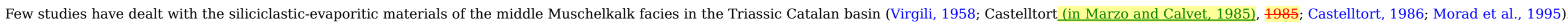

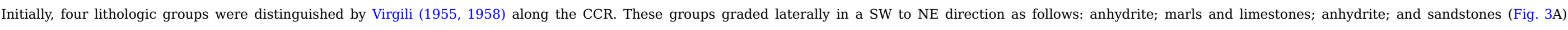

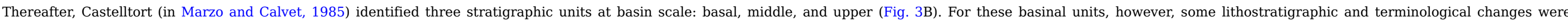

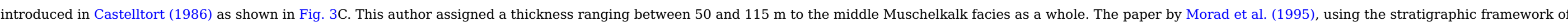

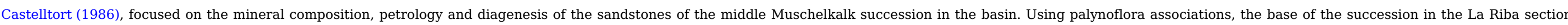

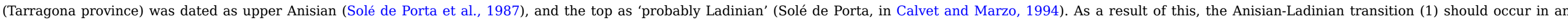
undetermined position of the middle Muschelkalk succession in the Triassic Catalan basin, and (2) an upper Anisian-lower Ladinian age is commonly assigned to this succession (Calvet and Marzo, 1994). 

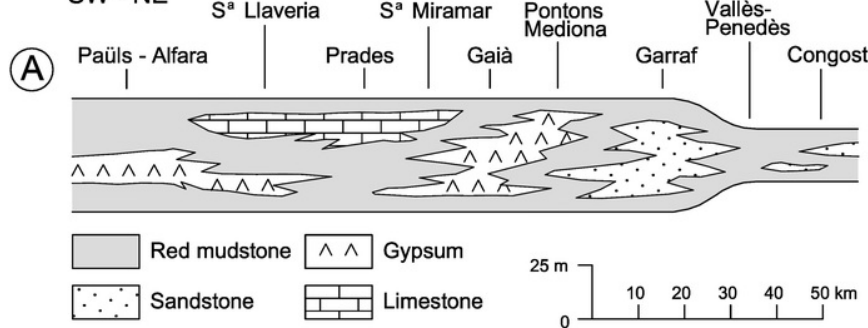

Virgili (1958)

(B) SW - NE

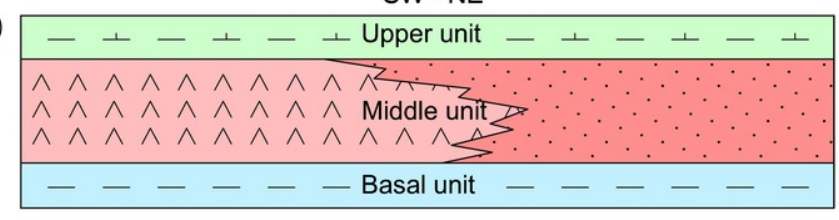

Castelltort (in Marzo and Calvet, 1985)

(C)

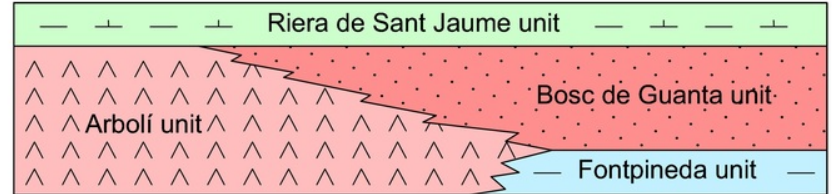

Castelltort (1986); Calvet \& Marzo (1994)

(D)

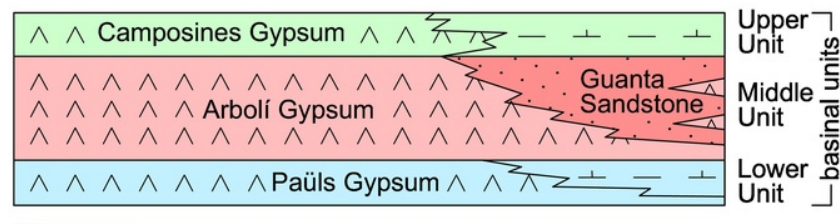

This paper

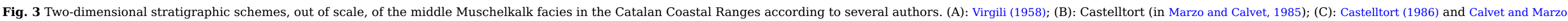
(1994); (D): present work.

\section{alt-text: Fig. 3}

\section{3 Methods}

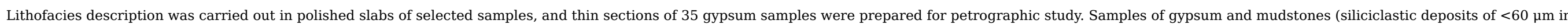

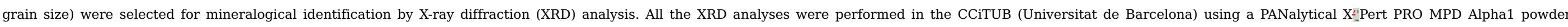

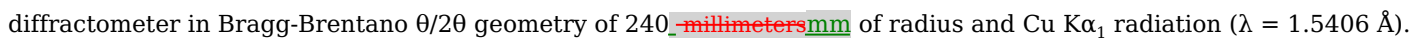

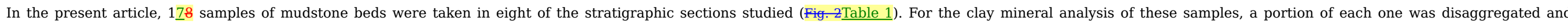

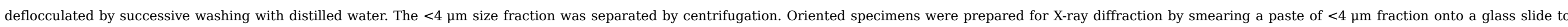

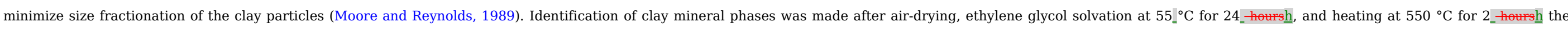
oriented mounds. 


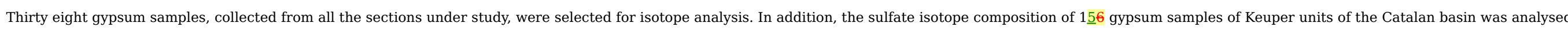
for comparison. For the same purpose, four anhydrite core samples from a deep drill intersecting the middle Muschelkalk interval in the subsurface of the adjacent Maestrat basin were isotopically analysed.

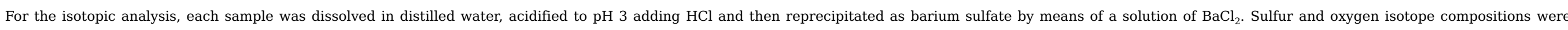

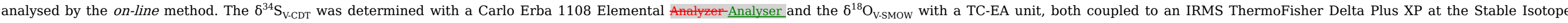

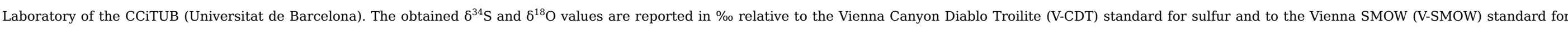

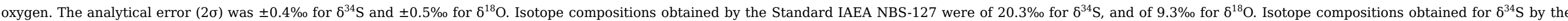
Standard IAEA SO- 5 were of $0.5 \%$ and by the Standard IAEA SO-6 were of $-=34.1 \%$.

\subsection{Mineralogy and evaporite petrology}

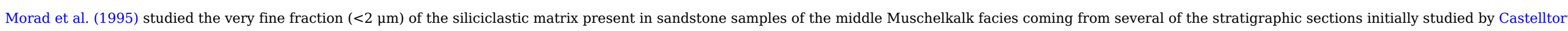

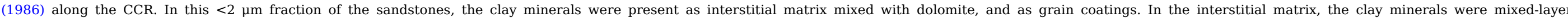
illite/smectite, regularly (corrensite) and irregularly (70:30), interstratified chlorite/smectite, and minor kaolinite.

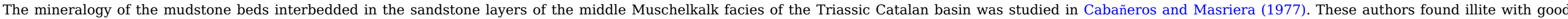
crystallinity as the major clay mineral, and also cited the possible presence of a poorly crystallized, interstratified or clay mineral of the chlorite or 'montmorillonite' types.

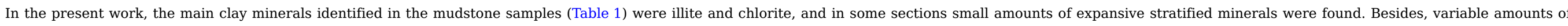
quartz, dolomite, magnesite, gypsum, feldspars, and hematite were present. This clay mineral association mainly reflects clastic origin.

Table 1 Mineralogy (XR diffraction) of sulfate, carbonate, and mudstone samples of the middle Muschelkalk facies in the Triassic Catalan basin

alt-text: Table 1

\begin{tabular}{|c|c|c|c|c|}
\hline Locality & Unit & Sample & Lithology & Mineralogy $^{\mathrm{a}}$ \\
\hline \multicolumn{5}{|l|}{ Middle Muschelkalk samples } \\
\hline \multirow{3}{*}{ Paüls quarry } & Camposines & MPA-4 & Secondary gypsum & gyp (88\%), dol (5\%), anh (3\%), q (2\%), cel (2\%) \\
\hline & Arbolí & MPA-3 & Secondary gypsum & gyp (83\%), q (12\%), anh (3\%), ru (2\%) \\
\hline & Paüls & MPA-1 & Secondary gypsum & gyp (83\%), anh (11\%), dol (6\%) \\
\hline \multirow{4}{*}{ Venta De Camposines section } & Camposines & MVC-6 & Secondary gypsum & gyp (68\%), mgs (11\%), cal (7\%), q (8\%), cel (6\%) \\
\hline & Camposines & MVC-8 & Secondary gypsum & gyp (95\%), anh (5\%) \\
\hline & Camposines & MVC-9 & Secondary gypsum & gyp (70\%), q (13\%), dol (12\%), anh (3\%), ru (2\%) \\
\hline & Paüls & MVC-2 & Secondary gypsum & gyp (66\%), dol (23\%), anh (5\%), cel (6\%) \\
\hline \multirow{4}{*}{ Masriudoms quarries } & Paüls & MMR-1 & Secondary gypsum & gyp (92\%), mgs (4\%), anh (4\%) \\
\hline & Paüls & MMR-2 & Mudstone & I, Ch, Ex (traces) \\
\hline & Paüls & MMR-3 & Mudstone & I, Ch, Ex (traces) \\
\hline & Paüls & MMR-5 & Secondary gypsum & gyp (85\%), q (10\%), anh (3\%), ru (2\%) \\
\hline \multirow{3}{*}{ Pratdip section } & Camposines & MPT-1 & Mudstone & I, Ch, Sm \\
\hline & Arbolí & MPT-2 & Secondary gypsum & gyp (88\%), dol (10\%), q (2\%) \\
\hline & Arbolí & MPT-3 & Mudstone & I, Ch, Ex (traces) \\
\hline
\end{tabular}




\begin{tabular}{|c|c|c|c|c|}
\hline & Arbolí & MPT-4 & Mudstone & I, Ch \\
\hline \multirow{2}{*}{ Pradell quarry } & Paüls & MPR-2 & Secondary gypsum & gyp (79\%), dol (8\%), cal (6\%), cel (3\%), q (2\%), anh (2\%) \\
\hline & Paüls & MPR-3 & Secondary gypsum & gyp (89\%), dol (7\%), cel (4\%) \\
\hline \multirow{2}{*}{ Coll de Falset section } & Arbolí & MCF-2 & Secondary gypsum & gyp (77\%), dol (12\%), q (7\%), anh (4\%) \\
\hline & Paüls & MCF-1 & Secondary gypsum & gyp (92\%), dol (8\%) \\
\hline \multirow{7}{*}{ Arbolí section } & Paüls & MAR-1:- & Secondary gypsum & gyp (95\%), cal (3\%), q (1\%), cel (1\%) \\
\hline & Arbolí & MAR-3:- & Secondary gypsum & gyp (94\%), dol (4\%), cel (2\%) \\
\hline & Arbolí & MAR-4:- & Mudstone & $\mathrm{I}, \mathrm{Ch}$ \\
\hline & Arbolí & MAR-5:- & Mudstone & $\mathrm{I}, \mathrm{Ch}$ \\
\hline & Arbolí & MAR-7:- & Mudstone & $\mathrm{I}, \mathrm{Ch}$ \\
\hline & Arbolí & MAR-10:- & Secondary gypsum & gyp (70\%), dol (28\%), cel (2\%), (hal) \\
\hline & Arbolí & MAR-11bis:- & Mudstone & I, Ch \\
\hline \multirow{3}{*}{ Rojalons section } & Arbolí & MRO-2 & Secondary gypsum & gyp (96\%), q (2\%), cel (2\%) \\
\hline & Arbolí & MRO-3 & Secondary gypsum & gyp (72\%), q (15\%), dol (9\%), anh (3\%), ru (1\%) \\
\hline & Camposines & MRO-6 & Mudstone & $\mathrm{I}, \mathrm{Ch}$ \\
\hline \multirow{8}{*}{ Querol composite section } & Arbolí & MQE-1 & Mudstone & I, Ch \\
\hline & Arbolí & MQE-2 & Mudstone & $\mathrm{I}, \mathrm{Ch}$ \\
\hline & Camposines & MQE-3 & Mudstone & I, $\mathrm{Ch}$ \\
\hline & Camposines & MQE-5 inferior & Secondary gypsum & gyp (46\%), dol (38\%), q (12\%), anh (2\%), cel (1\%), ru (1\%) (mus) \\
\hline & Camposines & MQE-7 & Mudstone & $\mathrm{I}, \mathrm{Ch}$ \\
\hline & Paüls & MQE-8 & Secondary gypsum & gyp (86\%), dol (13\%), q (1\%) \\
\hline & Arbolí & MQE-12 & Mudstone & $\mathrm{I}, \mathrm{Ch}$ \\
\hline & Arbolí & MQE-13 & Secondary gypsum & gyp (85\%), dol (7\%), q (7\%), ru (1\%) \\
\hline Corbera section & Arbolí & MFP-5 & Secondary gypsum & gyp (59\%), dol (27\%), q (9\%), anh (4\%), ru (1\%) (I) \\
\hline \multirow{3}{*}{ Vallirana mine } & Paüls & MVA-1 & Mudstone & I, $\mathrm{Ch}$ \\
\hline & Paüls & MVA-3 & Secondary gypsum & gyp (77\%), anh (12\%), dol (6\%), q (2\%), cel (2\%) \\
\hline & Paüls & MVA-5 & Secondary gypsum & gyp (66\%), anh (31\%), dol (2\%) \\
\hline \multirow{3}{*}{ Figaró section } & Arbolí & MFG-1 & Mudstone & $\mathrm{I}, \mathrm{Ch}$ \\
\hline & Arbolí & MFG-2 & Secondary gypsum & gyp (97\%), q (3\%) \\
\hline & Arbolí & MFG-4 & Secondary gypsum & gyp (85\%), dol (7\%), anh (5\%), q (3\%) \\
\hline \multirow{2}{*}{ Aiguafreda section } & Arbolí & MMC-1 & Secondary gypsum & guix (99\%), quars (1\%) \\
\hline & Arbolí & MMC-3 & Secondary gypsum & gyp (64\%), dol (28\%), q (4\%), anh (4\%) \\
\hline \multirow{2}{*}{ La Puda mine } & Paüls & MLP-4 & Secondary gypsum & gyp (88\%), q (5\%), an (2\%), cal (2\%), cel (2\%), ru (1\%) \\
\hline & Arbolí & MLP-7 & Secondary gypsum & gyp (91\%), q (2\%), dol (4\%), cel (1\%), cal (1\%) \\
\hline
\end{tabular}




\begin{tabular}{|c|c|c|c|c|}
\hline \multirow{4}{*}{$\begin{array}{l}\text { Bobalar-1 borehole- } \\
\text { (Maestrat Basin) }\end{array}$} & Undetermined & 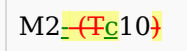 & Anhydrite & anh (93\%), mgs (5\%), q (2\%), (ru, mus) \\
\hline & Undetermined & M5_(T둔) & Anhydrite & anh (96\%), q (2\%), mgs (1\%) \\
\hline & Undetermined & M13_(T둔) & Anhydrite & anh $(96 \%)$, mgs (2\%), hal (1\%), q $(<1 \%)$, ru $(<1 \%)$ \\
\hline & Undetermined & M14_(Tㅁ1) & Anhydrite & anh (85\%), mgs (8\%), q (5\%), ru (1\%), zr (1\%) \\
\hline \multicolumn{5}{|l|}{ Keuper samples } \\
\hline Rasquera & Miravet & RA12 & Secondary gypsum & gyp (88\%), q (4\%), anh (4\%), cel (2\%), cal (2\%) \\
\hline \multirow{5}{*}{ Espinagosa } & Miravet & ES5 & Anhydrite & anh $(99 \%)$, mgs $(1 \%)$ \\
\hline & Miravet & ES7 & Secondary gypsum & gyp (85\%), dol (9\%), anh (2\%), q (2\%), cel (2\%) \\
\hline & Miravet & ES14 & Anhydrite & anh (84\%), dol (10\%), gyp (6\%) \\
\hline & El Molar & ES22 & Secondary gypsum & gyp (83\%), q (8\%), mgs (6\%), anh (3\%) \\
\hline & El Molar & ES24 & Secondary gypsum & gyp (72\%), anh (9\%), ar (8\%), q (7\%), cal (3\%), cel (2\%) \\
\hline \multirow{2}{*}{ Gallicant } & El Molar & GA28 & Secondary gypsum & gyp (82\%), anh (8\%), mgs (5\%), q (3\%), cel (2\%) \\
\hline & El Molar & GA29 & Secondary gypsum & gyp (88\%), cel (6\%), q (4\%), anh (3\%) \\
\hline \multirow{3}{*}{ Corbera } & Miravet & $\mathrm{CO} 3$ & Secondary gypsum & gyp (82\%), anh (8\%), mgs (5\%), q (3\%), cel (2\%) \\
\hline & Miravet & $\mathrm{CO} 16$ & Anhydrite & anh (97\%), dol (1\%), q (2\%) \\
\hline & El Molar & $\mathrm{CO} 23$ & Secondary gypsum & gyp (50\%), anh (43\%), q (3\%), mgs (3\%), cel (1\%) \\
\hline
\end{tabular}

Minerals: anh anhydrite; ar aragonite; cal calcite, cel celestite; dol dolomite; gyp gypsum; hal halite; hem hematite; mgs magnesite; mus muscovite; q quartz; ru rutile; zr zircon]

Clays: Ch chlorite; Ex expansive clays; I illite; K kaolinite; S smectite,

a Semiquantitative for secondary gypsum and anhydrite; for mudstones, the results correspond to the $<2 \_\mu m$ fraction.

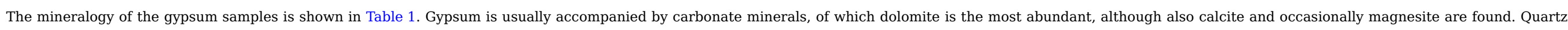
anhydrite and celestite are common minerals, and less frequent minerals in some samples are muscovite, halite, rutile and zircon.

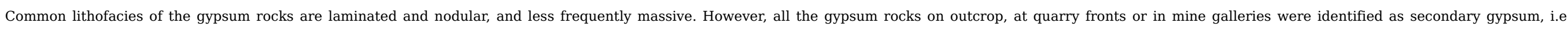

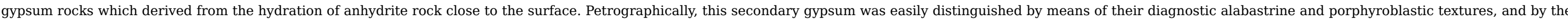

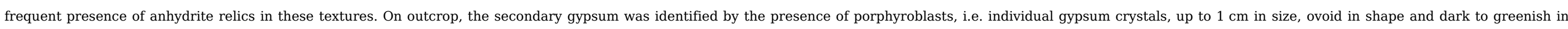
color.

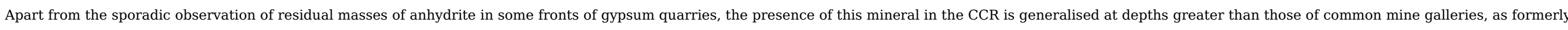

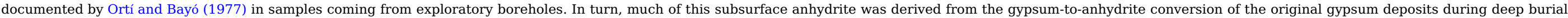
Some of the anhydrite, however, could originate from synsedimentary growth in sabkha environments. This is mainly the case of the nodular lithofacies of the today!s secondary gypsum observed on outcrop.

Salt bodies have not been documented in the CCR. Only isolated pseudomorphs of halite crystals were observed by us very locally.

\section{5.}

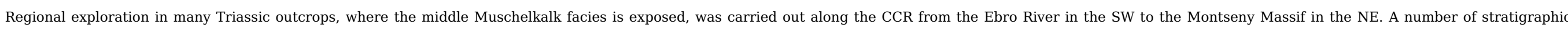

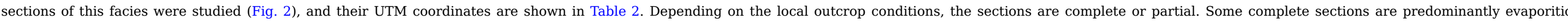

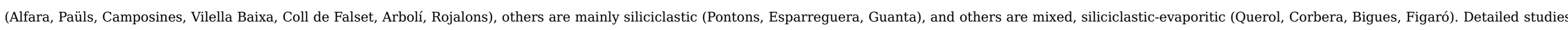




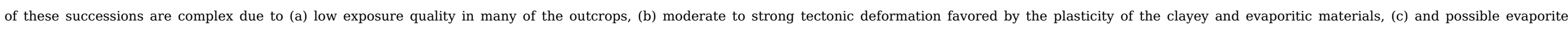

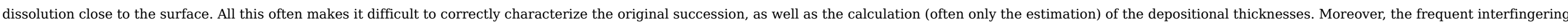
both laterally and vertically between evaporites and siliciclastics masks the precise boundaries between the lithostratigraphic units.

Table 2 Coordinates UTM (UTM 31N/ETR-S89) of the sections.

alt-text: Table 2

\section{Sections}

Coordinates UTM

\begin{tabular}{|c|c|c|c|c|}
\hline Alfara & - & $280_{2} 154$ & $4 \_527,586$ & 350 \\
\hline Paüls & & $283_{4} 476$ & $4{ }_{\alpha} 535_{\alpha} 250$ & 379 \\
\hline Camposines & Paüls Gypsum unit & $295_{2} 750$ & $4,552,508$ & 253 \\
\hline Camposines & Arbolí Gypsum unit & $295_{L} 049$ & $44_{\perp} 552,524$ & 191 \\
\hline Camposines & Camposines Gypsum unit & $295 \lcm{169}$ & $4,552,811$ & 255 \\
\hline Vilella Baixa & & 310,110 & $44_{\perp} 566_{\perp} 946$ & 260 \\
\hline Masriudoms & & $322 / 316$ & $4,543_{2} 044$ & 200 \\
\hline Pratdip & & $321_{2} 667$ & $4,547,201$ & 280 \\
\hline Colldejou & & $322_{2} 881$ & $4,551_{\perp} 252$ & 370 \\
\hline Pradell & & $321_{2} 594$ & $4,557,551$ & 455 \\
\hline Coll de Falset & & $319_{2} 437$ & $4,557_{2} 303$ & 537 \\
\hline Arbolí & & $328_{4} 600$ & $4,5666_{\alpha} 524$ & 785 \\
\hline Rojalons & & 345,655 & $44_{\alpha} 578_{\alpha} 898$ & 841 \\
\hline Querol & Paüls Gypsum unit & $365_{4} 748$ & $4,585_{2} 810$ & 531 \\
\hline Querol & Camposines Gypsum unit & $365_{2} 656$ & $4,587_{2} 286$ & 435 \\
\hline Pontons & & $376_{2} 896$ & $4,585_{\perp} 803$ & 554 \\
\hline Corbera & & $412_{\alpha} 211$ & $44_{\perp} 585_{\perp} 908$ & 265 \\
\hline Vallirana & & $411_{2} 045$ & $4,579_{2} 891$ & 226 \\
\hline Esparreguera & & $403_{L} 750$ & $4,601_{2} 834$ & 360 \\
\hline La Puda & & $4 0 6 \longdiv { 3 } 3 0 4$ & $44_{\alpha} 602_{\alpha} 901$ & 154 \\
\hline Guanta & & $426_{\alpha} 182$ & $4,610_{2} 242$ & 420 \\
\hline Bigues & & $434_{2} 002$ & $44_{L} 615_{L} 899$ & 317 \\
\hline Figaró & & 437,335 & $4,618_{2} 216$ & 518 \\
\hline Aiguafreda & & $437 \_479$ & $44_{\perp} 621_{\perp} 947$ & 451 \\
\hline
\end{tabular}

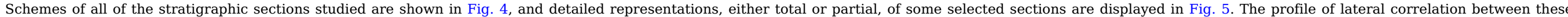

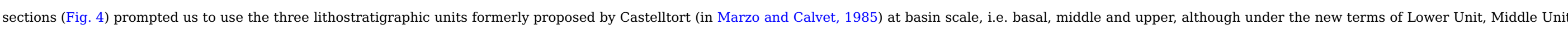




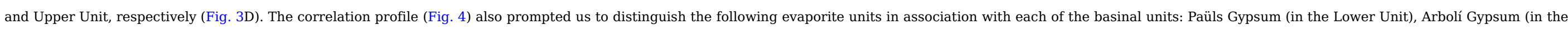

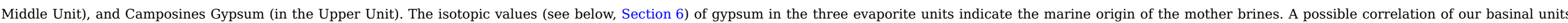
with the lithologic groups of Virgili $(1955,1958)$ is shown in Table 3. This table also includes observations of other authors on the middle Muschelkalk facies in the CCR.

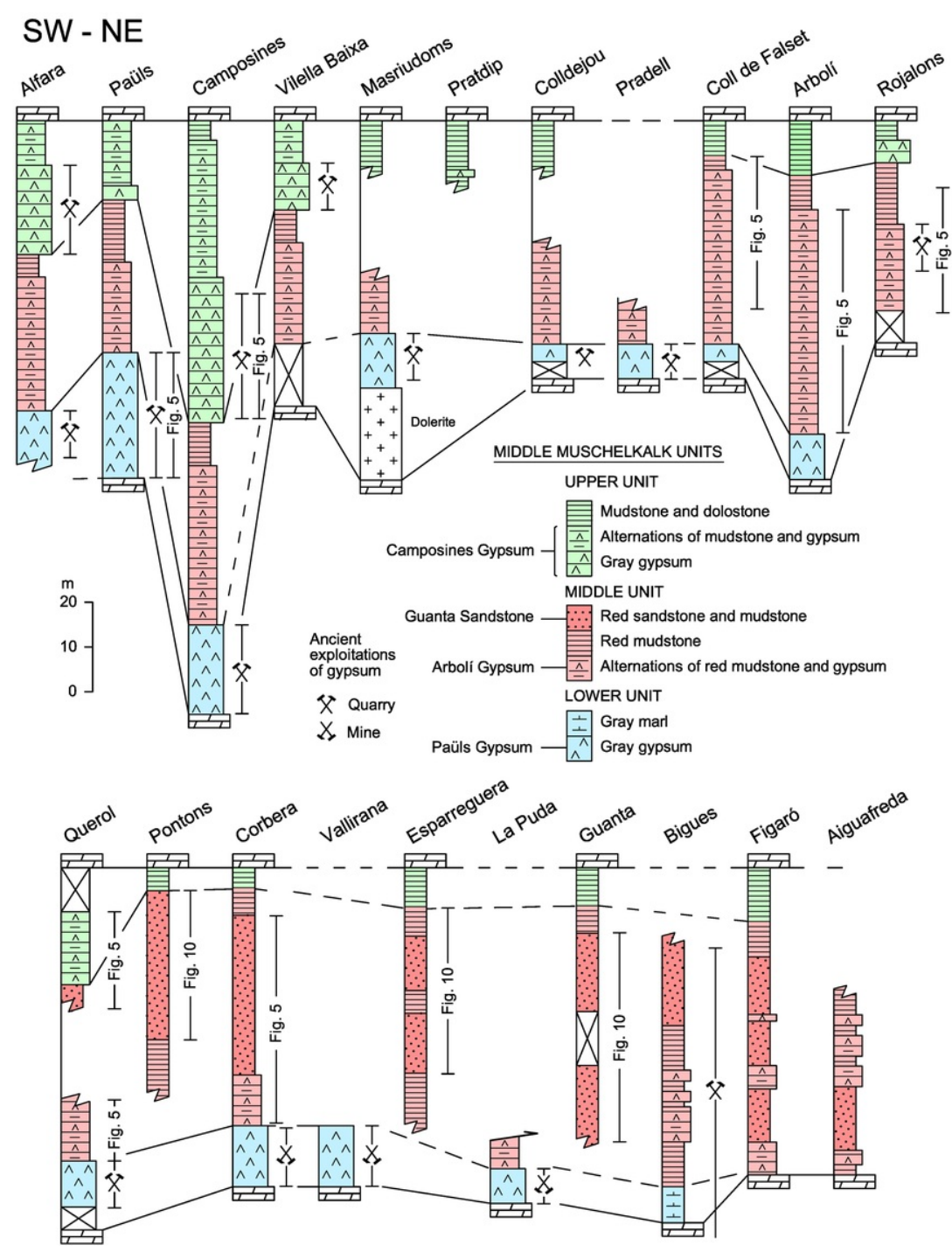

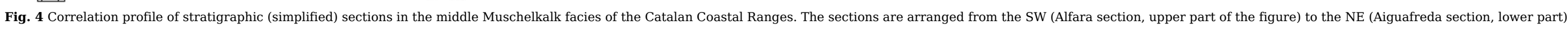
Location of the sections in Fig. 2 . 


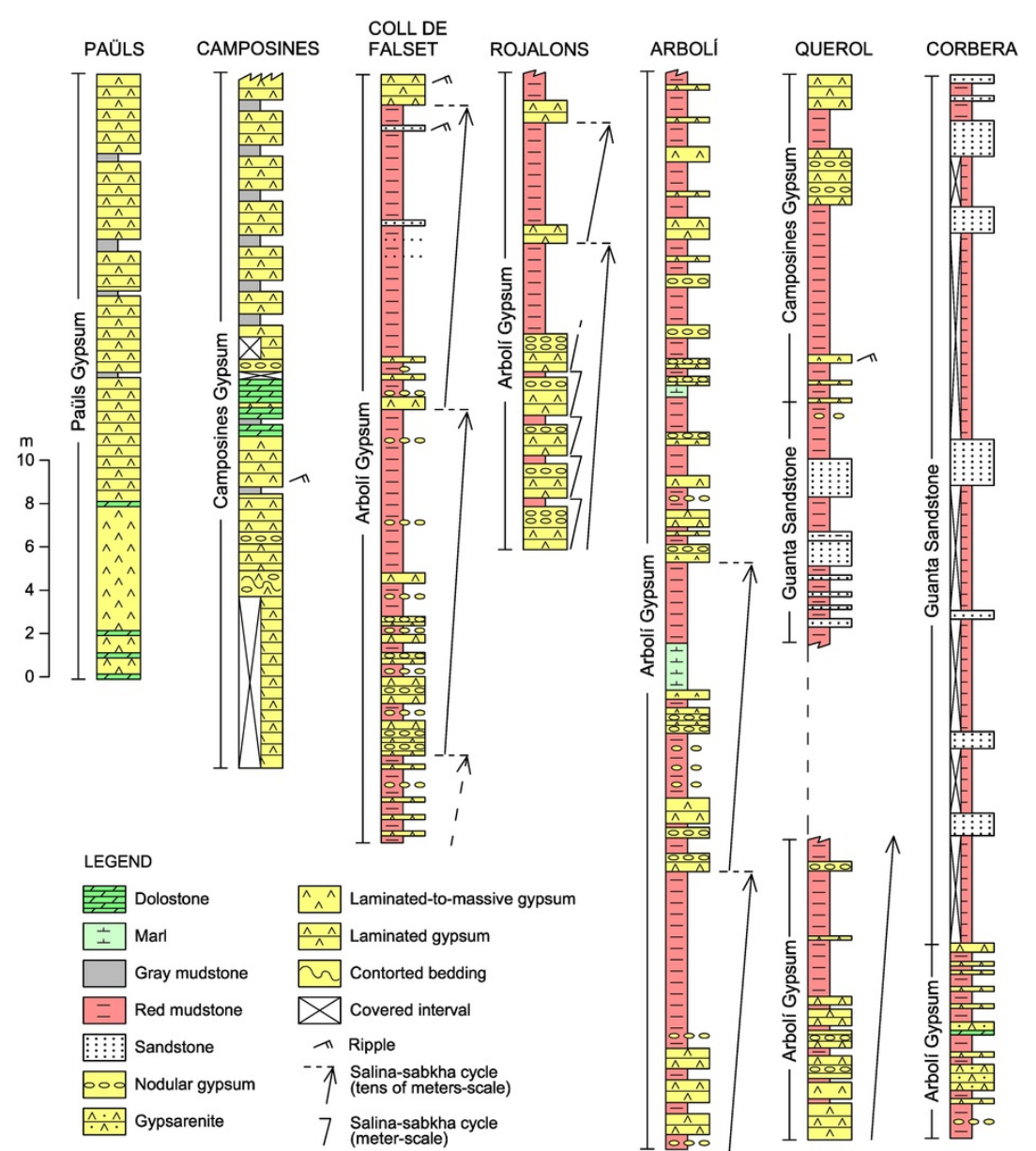

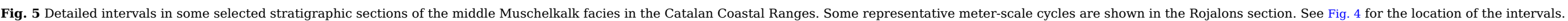
alt-text: Fig. 5

Table 3 Stratigraphic descriptions, according to different authors, of the middle Muschelkalk facies in the Triassic Catalan basin. CCR: Catalan Coastal Ranges.

alt-text: Table 3

Virgili $(1955,1958)$ (geographic sectors in the CCR according to Virgili, 1958)

"Stratigraphic conclusions" in the southern sector of the CCR (sections: Alfara, Paüls, Rasquera and Camposines) (p. 90-_92): Intervals of the general succession in this sector:

- Yellowish and iridescent marls: 2--5 m (Top);

- Yellow or slightly red clays: 5--50 m of anhydrite and white or reddish gypsum with clay intercalations of the same tone: 18 -- $60 \mathrm{~m}$;

- Red clays that can contain fine gypsum veins: 10--15 m (Base).

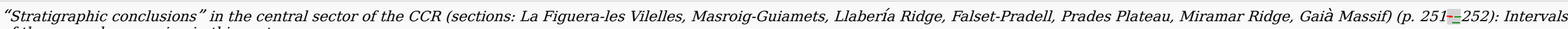
of the general succession in this sector:

- Gray and blue marls with gypsum films in the central part: 5-=15 m (Top); 
Red and iridescent clays that in the Gaià block (NW end of the central region) intercalate reddish, clayey sandstones: 35-=60 m;

- Gypsum and anhydrite in thick layers intercalating thin beds of red and blue clays: 10-_-30 m

Red and iridescent clays that locally (southern end of the sector) intercalate thin beds of red sandstones: 10--15 m (Base).

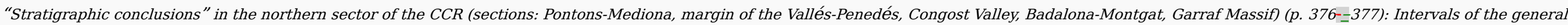
succession in this sector:

- Red and iridescent clay which in the uppermost beds is marly and yellowish: 4-=15 m (Top);

- Clay-rich, red sandstone, which smoothly changes to the upper and lower levels: 10-_30 m;

- Red and iridescent clay bearing gypsum and anhydrite intercalations; these intercalations may be absent or may reach up to $7 \mathrm{~m}$ in thickness: 15 --_30 $\mathrm{m}$ (Base).

\section{Possible correlation between the stratigraphic intervals in Virgili $(1955,1958)$ and the units distinguished in this paper:}

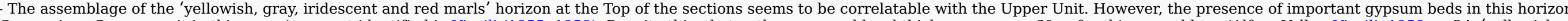

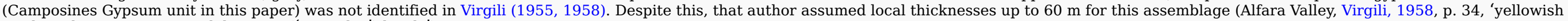
marls with porous massive dolostones ('carniolas') levels'),

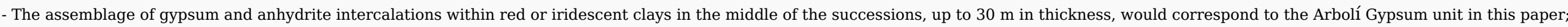

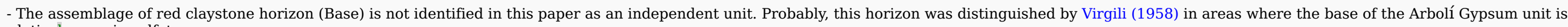
relatively poor in sulfates.

Calvet and Marzo (1994)

The thickness of the whole succession varies from 50 to $115 \mathrm{~m}$ and can be divided into four units. From base to top and in $E$-W direction, the units are the following:

- Fontpineda Lutite and Gypsum unit: it is formed by calcium sulfates deposited on a lutitic-evaporitic supratidal plain. It is $10-25 \mathrm{~m}$ thick;

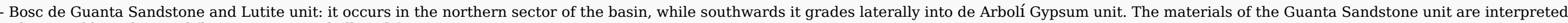
as deposited by ephemeral flows in a terminal alluvial fan system;

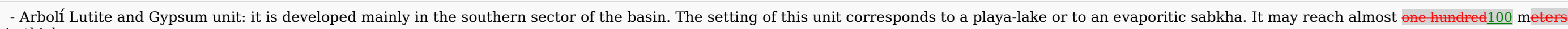
in thickness;

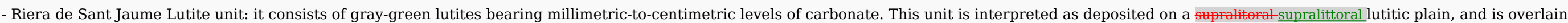
by the carbonates of the upper Muschelkalk facies throughout the basin. It is $5_{--}^{-} 10 \mathrm{~m}$ thick.

Ortí et al. (2017)

- In the Catalan basin, the middle Muschelkalk evaporites are associated with abundant siliciclastic host material (claystones in reddish or gray tones and sandstones);

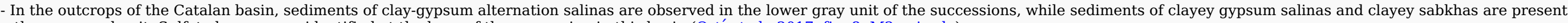
in the upper red unit. Sulfate lagoons are identified at the base of the succession in this basin (Ortí et al., 2017, fig. 8, M2 episode).

\subsubsection{Paüls Gypsum unit}

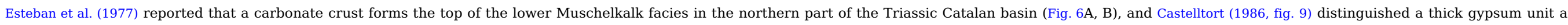

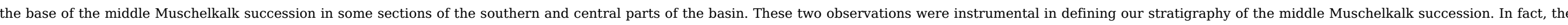

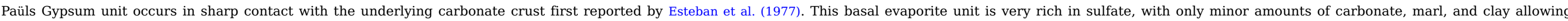

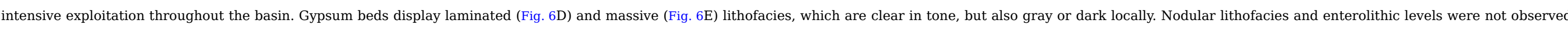
in the gypsum beds. 

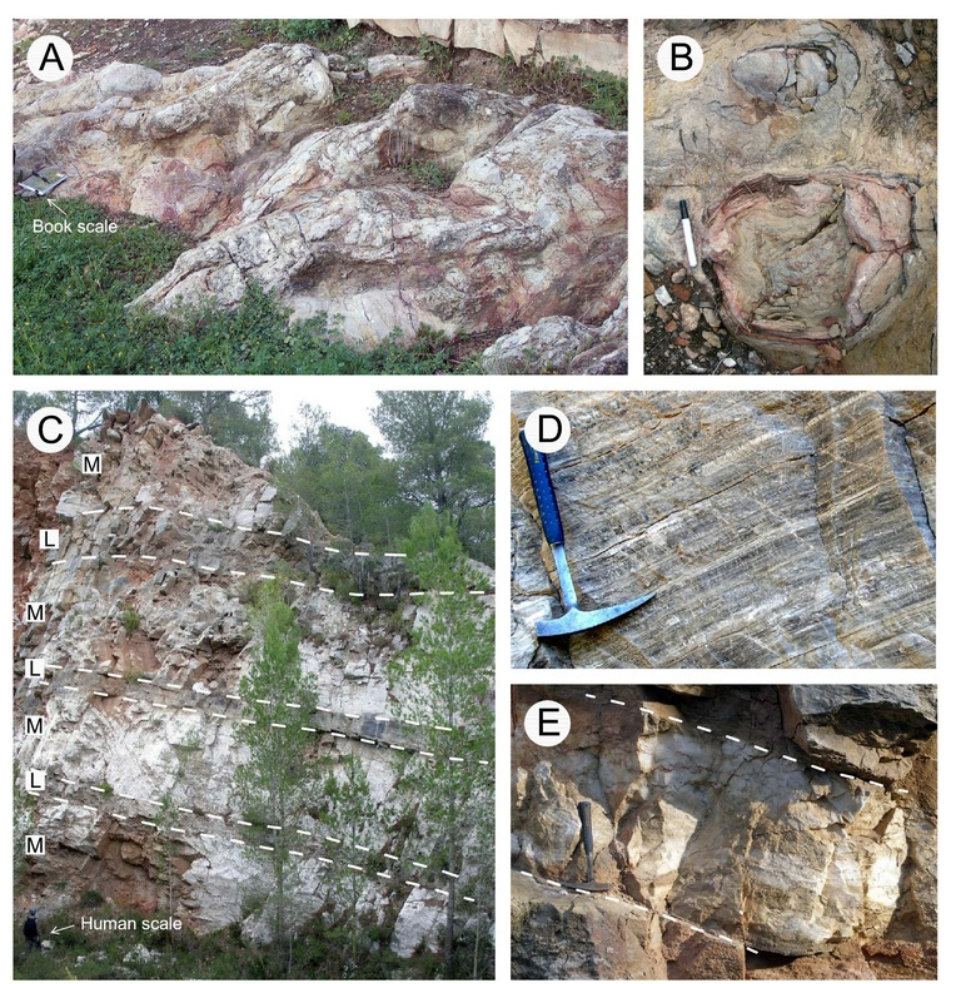

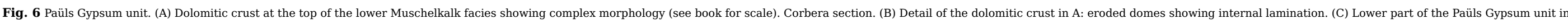

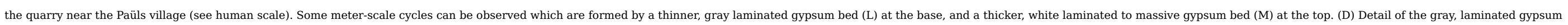
lithofacies (small quarry in the Camposines section). (E) Detail of the white, massive gypsum lithofacies at the top of the meter-scale cycles (Pradell quarry). Hammer for scale.

\section{alt-text: Fig. 6}

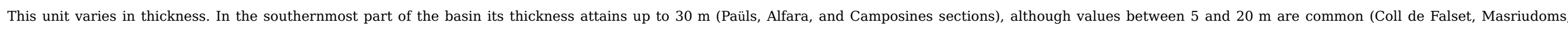

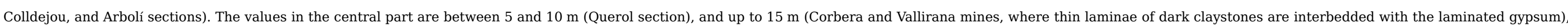

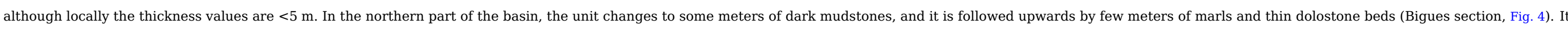

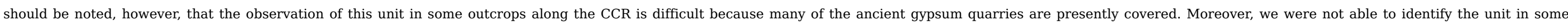
sections, because of structural disruption or local dissolution.

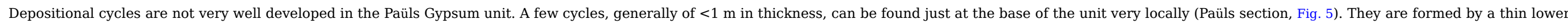

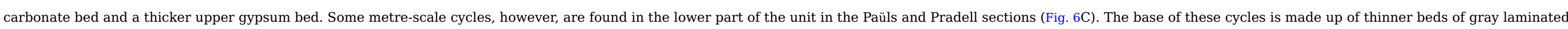
gypsum and dark claystone, and the top is composed of thicker beds of laminated gypsum. Locally, however, massive gypsum overlies the laminated beds at the top of the cycle (Fig. $6 \mathrm{E}$ ).

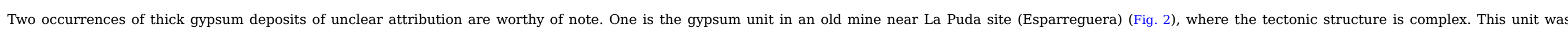

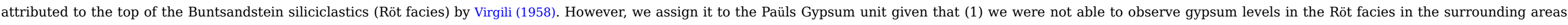

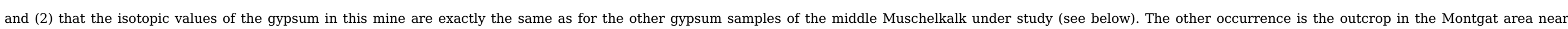
Barcelona, which was assigned to the middle Muschelkalk facies also by Virgili (1958). In this case, our isotopic values of gypsum clearly indicate a Keuper attribution (see below). 


\subsection{Interpretation}

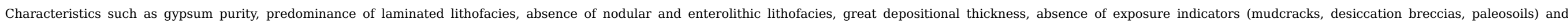

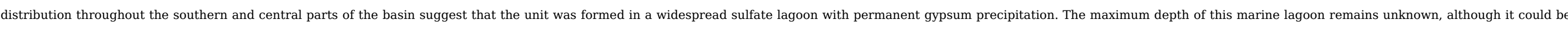

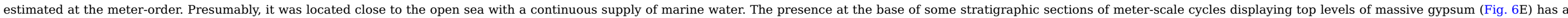
doubtful interpretation, although this lithofacies does not show characteristics of sabkha deposits.

\subsubsection{Arbolí Gypsum unit}

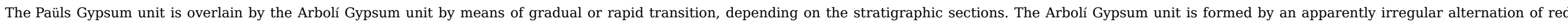

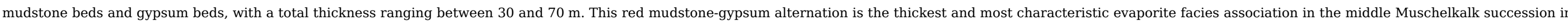

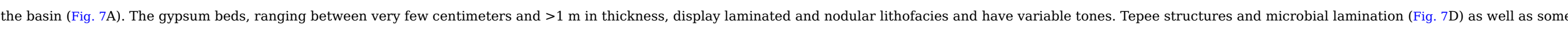

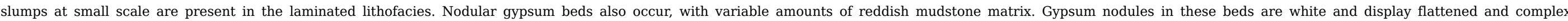

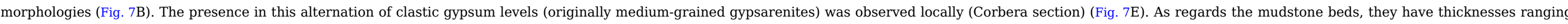

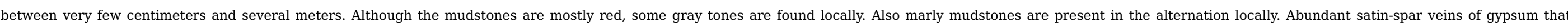
cements fractures can be present in the mudstone beds. 


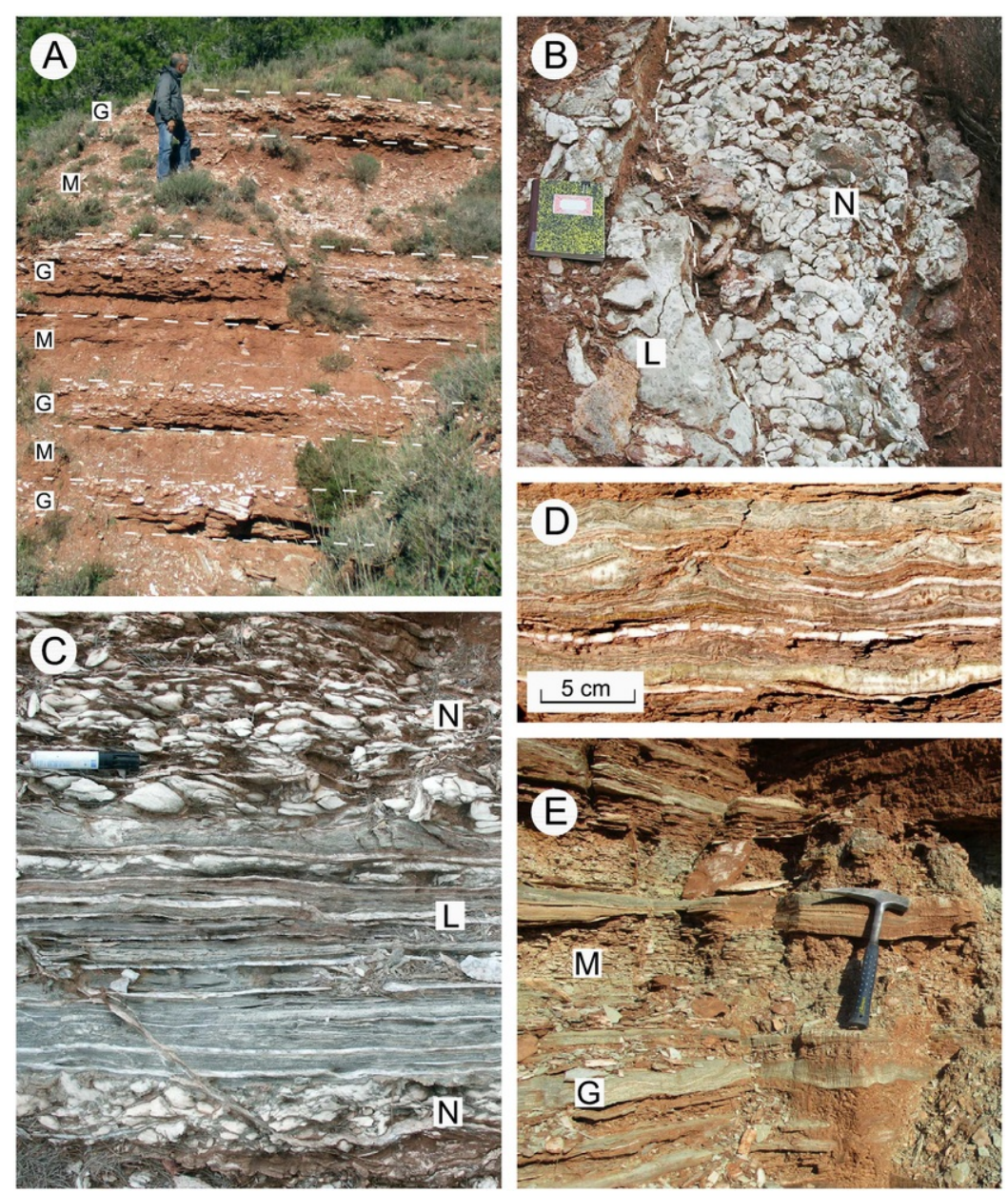

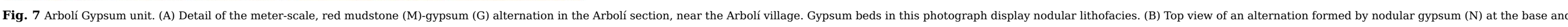

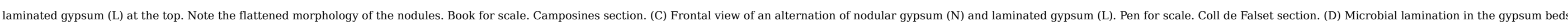

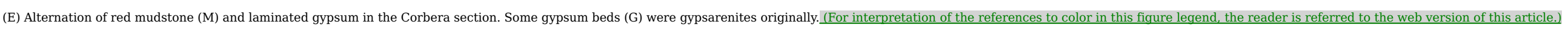
alt-text: Fig. 7

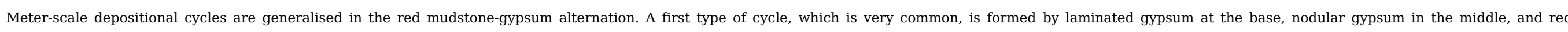

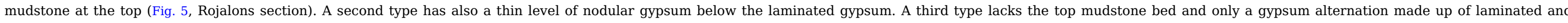

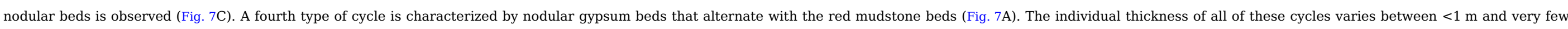

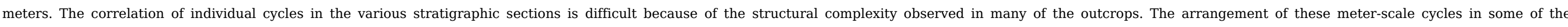
stratigraphic sections studied also suggest the presence of decameter-scale cycles (Fig. 5)

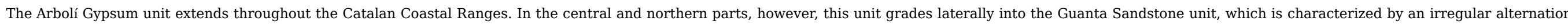

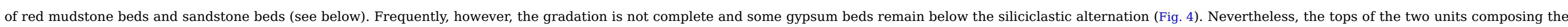
Middle Unit (Arbolí Gypsum and Guanta Sandstone) show predominance of red mudstones throughout the basin. 


\subsection{Interpretation (Arbolí Gypsum unit)}

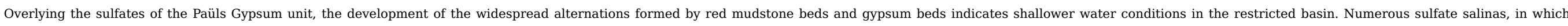

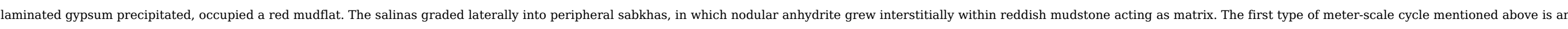

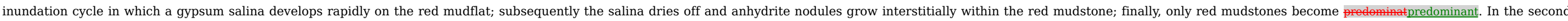

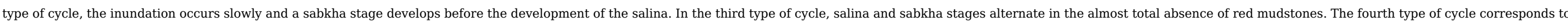

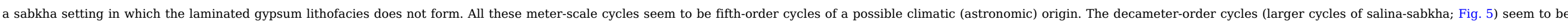

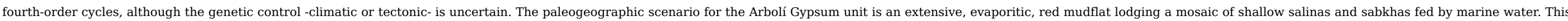
evaporitic mudflat was sensitive to record depositional cyclicity of high-frequency.

\subsubsection{Camposines Gypsum unit}

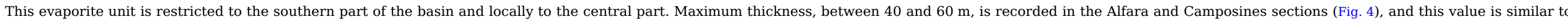

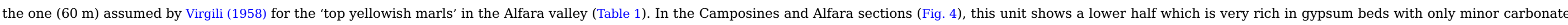

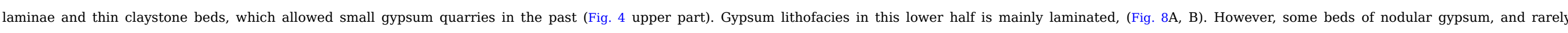

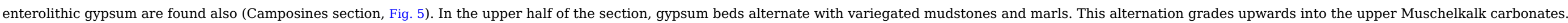
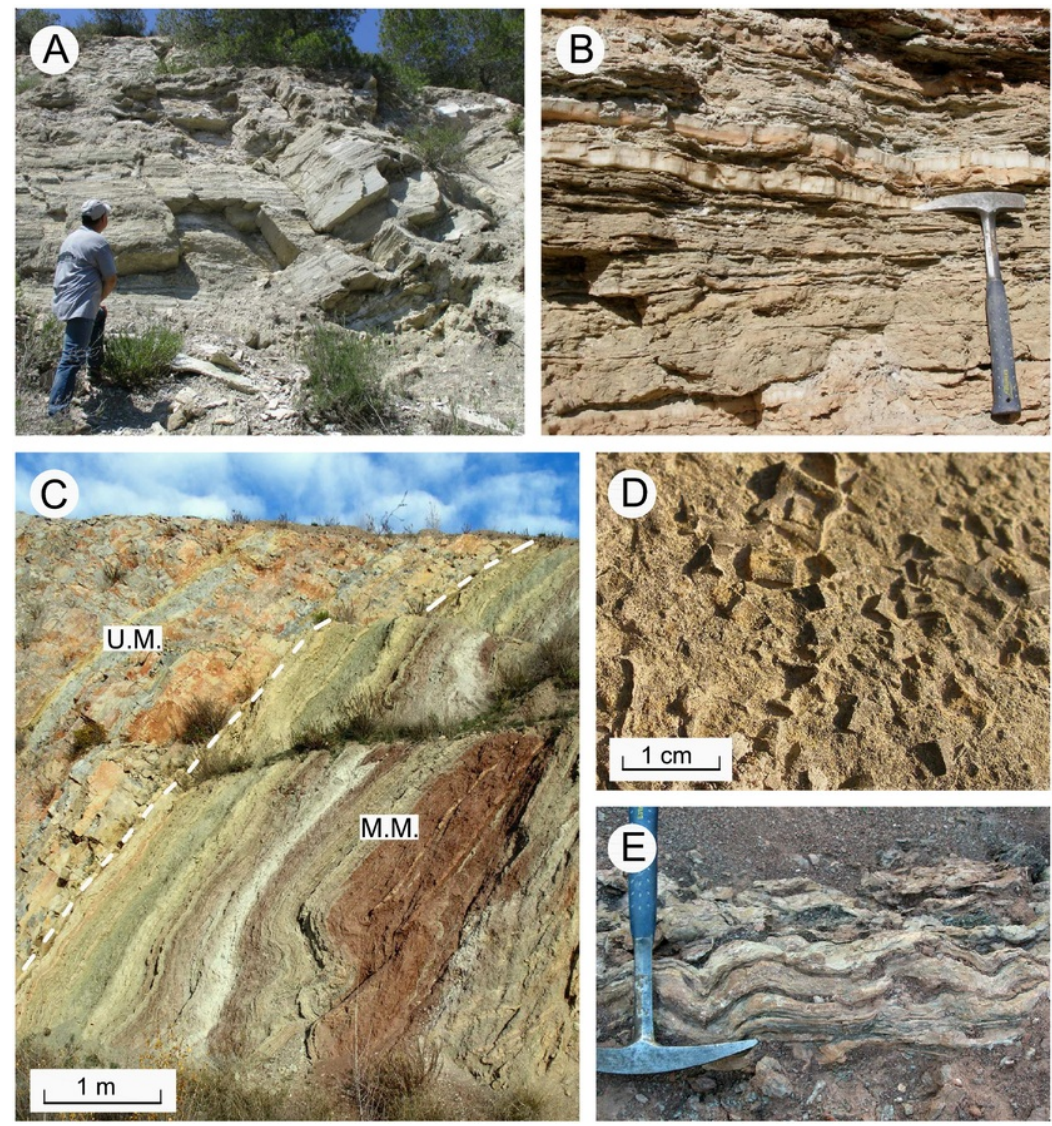


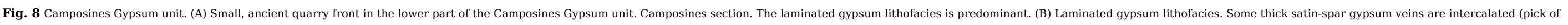

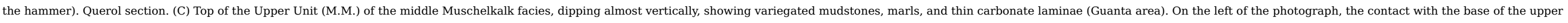

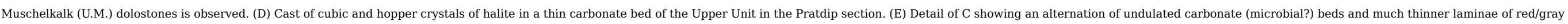
mudstones.(For interpretation of the references to color in this ficure lecend, the reader is referred to the web version of this article.)

\section{alt-text: Fig. 8}

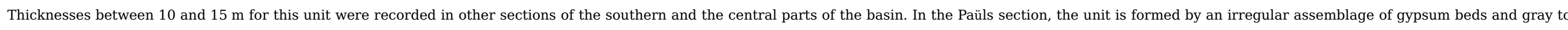

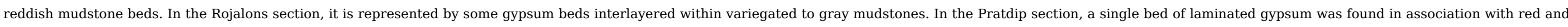

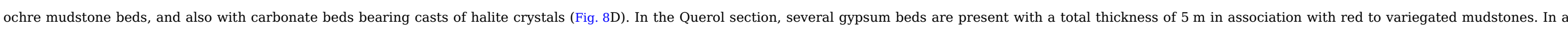
northeastern direction (Fig. 8C), this unit grades into mudstones, marls, and carbonate beds (Fig. 8E) with a total thickness of only 5 to $15 \mathrm{~m}$, where evaporites were not observed.

\subsection{Interpretation}

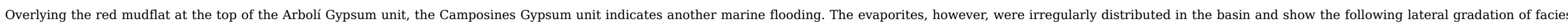

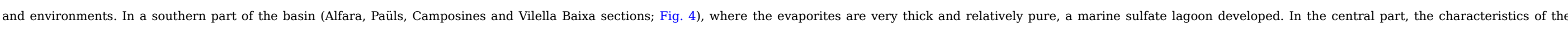

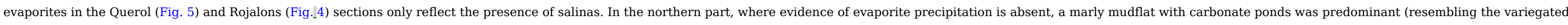

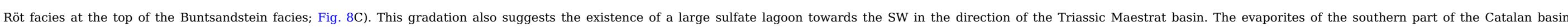

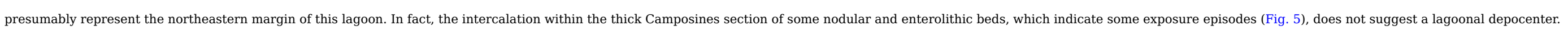

\section{6. $\underline{6}$ Isotopes. Results and interpretation}

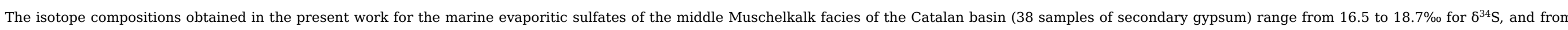

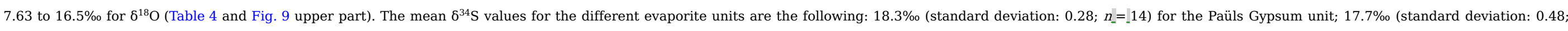

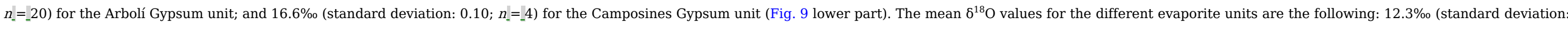

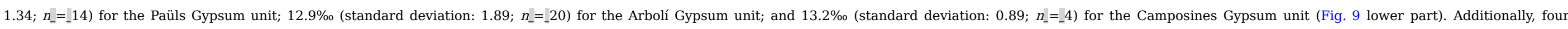

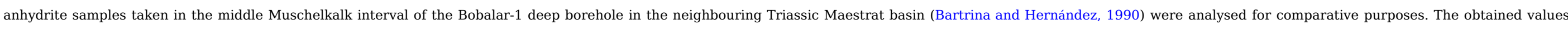
(Table 4) range from 17.3 to $17.5 \%$ in $8^{34} \mathrm{~S}$ and from 12.1 to 13.0 in $8^{18} \mathrm{O}$.

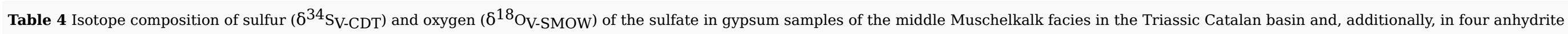

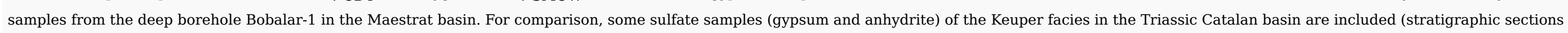
from Salvany, 1986). Depths of the anhydrite samples in the Bobalar-1 borehole: M2 (core 10), 1782.3 m; M5 (core 10), 1787.3 m; M13 (core 11 ), 1857.0 m; M14 (core 11), 1858.0 m.

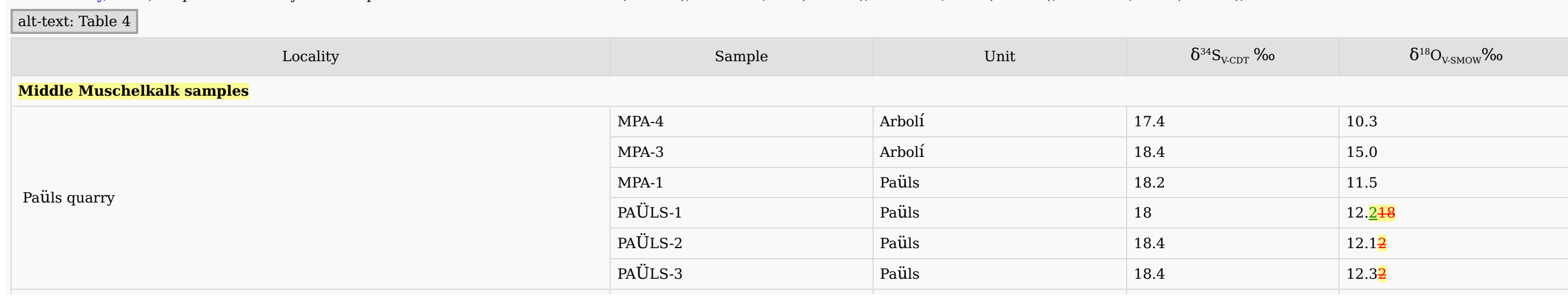


Venta De Camposines section

\section{Masriudoms quarries}

Pratdip section

Pradell quarry

Coll de Falset section

Arbolí section

Rojalons section

Querol compesite-section

Corbera section

Vallirana mine

La Puda mine

Figaró section

Aiguafreda section

Bobalar-1 borehole (Maestrat Basin)

\begin{tabular}{|c|c|c|c|}
\hline MVC-6 & Camposines & 16.7 & 13.5 \\
\hline MVC-8 & Camposines & 16.5 & 12.7 \\
\hline MVC-9 & Camposines & 16.6 & 14.3 \\
\hline VC-1 & Arbolí & 17.5 & 12.44 \\
\hline VC-2 & Arbolí & 17.1 & 12.31 \\
\hline MVC-2 & Paüls & 18.1 & 15.5 \\
\hline MMR-1 & Paüls & 18.7 & 11.61 \\
\hline MMR-5 & Arbolí & 17.5 & 16.5 \\
\hline MPT-2 & Arbolí & 18.5 & 13.1 \\
\hline MPR-2 & Paüls & 18.2 & 14.3 \\
\hline MPR-3 & Paüls & 18.7 & 13.3 \\
\hline MCF-2 & Arbolí & 18.0 & 12.9 \\
\hline MCF-1 & Paüls & 17.8 & 11.9 \\
\hline MAR-3: & Arbolí & 17.5 & 13.0 \\
\hline MAR-10: & Arbolí & 18.4 & 15.2 \\
\hline MAR-1: & Paüls & 18.5 & $11.8 \theta$ \\
\hline MRO-2 & Arbolí & 18.7 & 13.71 \\
\hline MRO-3 & Arbolí & 17.2 & 12.67 \\
\hline MQE-5 inferior & Camposines & 16.5 & 12.3 \\
\hline MQE-13 & Arbolí & 18.0 & 14.6 \\
\hline MQE-8 & Paüls & 18.7 & 12.2 \\
\hline MFP-5 & Arbolí & 17.7 & $12 . \underline{5} 49$ \\
\hline MVA-3 & Paüls & 18.3 & $12 . \underline{4} 36$ \\
\hline MVA-5 & Paüls & 18.1 & 11.89 \\
\hline MLP-7 & Arbolí & 17.1 & 7.63 \\
\hline MLP-4 & Paüls & 18.4 & 9.877 \\
\hline MFG-2 & Arbolí & 17.6 & $11 . \underline{6} 59$ \\
\hline MFG-4 & Arbolí & 17.5 & $11 . \underline{8} 77$ \\
\hline F-1 & Arbolí & 17.8 & 14.33 \\
\hline F-2 & Arbolí & 17.9 & $13 . \underline{8} 79$ \\
\hline MMC-1 & Arbolí & 17.2 & 12.7 \\
\hline MMC-3 & Arbolí & 17.6 & 12.2 \\
\hline M2= (T1ㅜ) & Undetermined & 17.5 & 13.0 \\
\hline 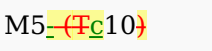 & Undetermined & 17.4 & 12.8 \\
\hline
\end{tabular}


Keuper samples

\begin{tabular}{|c|c|c|c|c|}
\hline Rasquera & RA12 & Miravet & 14.9 & 16.6 \\
\hline \multirow{2}{*}{ Cabacés-Falset } & $\mathrm{K}-1$ & El Molar & 14.7 & 15.1 \\
\hline & $\mathrm{K}-2$ & El Molar & 14.8 & 15.0 \\
\hline \multirow{2}{*}{ Gallicant } & GA28 & El Molar & 15.0 & 16.5 \\
\hline & GA29 & El Molar & 14.8 & 15.8 \\
\hline \multirow{5}{*}{ Espinagosa } & ES5 & Miravet & 15.1 & 12.9 \\
\hline & ES7 & Miravet & 15.4 & 13.8 \\
\hline & ES14 & Miravet & 15.3 & 12.7 \\
\hline & ES22 & El Molar & 14.6 & 13.5 \\
\hline & ES24 & El Molar & 14.2 & 12.6 \\
\hline \multirow{3}{*}{ Corbera } & $\mathrm{CO} 3$ & Miravet & 15.4 & 11.3 \\
\hline & CO16 & Miravet & 15.3 & 11.9 \\
\hline & $\mathrm{CO} 23$ & El Molar & 14.5 & 14.1 \\
\hline \multirow{2}{*}{ Montgat } & MG-1 & Miravet & 15.4 & 11.6 \\
\hline & MG-3 & Miravet & 15.0 & 12.9 \\
\hline
\end{tabular}



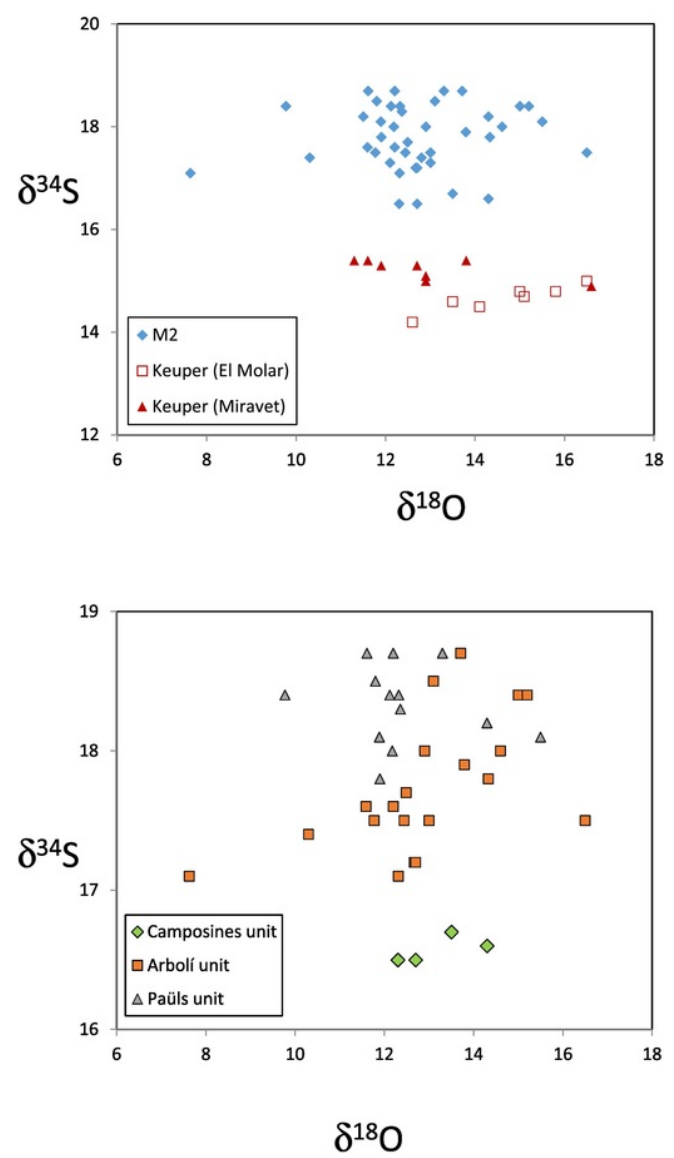

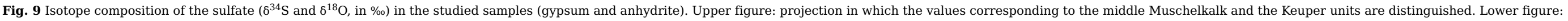
projection in which the values corresponding to the evaporite units of the middle Muschelkalk facies in the Catalan basin are distinguished.

\section{alt-text: Fig. 9}

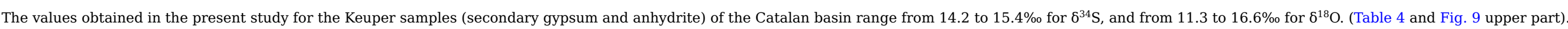

In the light of the foregoing data, the following aspects should be highlighted:

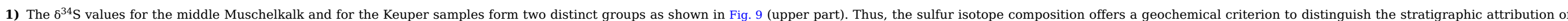
these Triassic evaporite units which commonly show very similar facies.

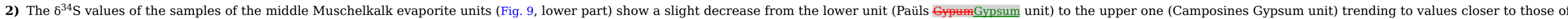
the Keuper samples.

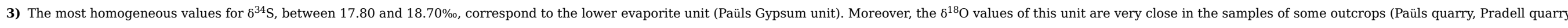
Vallirana mine; Table 4).

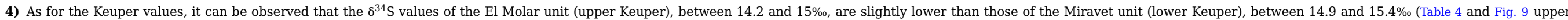




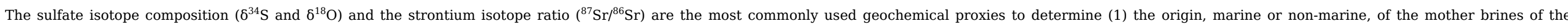

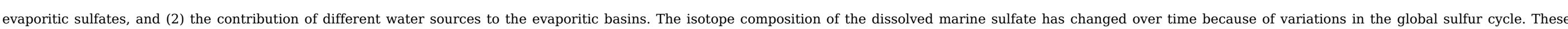

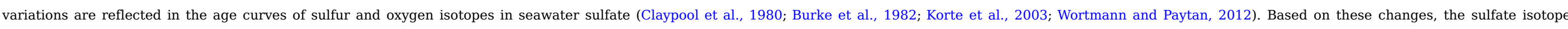
composition of the evaporitic sulfates may also indicate their age (Utrilla et al., 1992; Bernasconi et al., 2017)

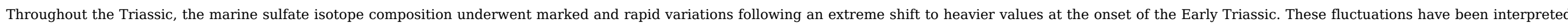

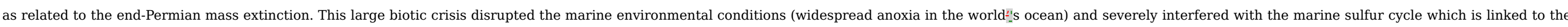
carbon and oxygen cycles (Song et al., 2014; Bernasconi et al., 2017).

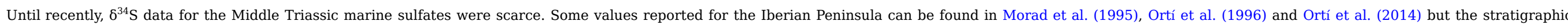
allocation of the samples analysed in these works is imprecise in some cases.

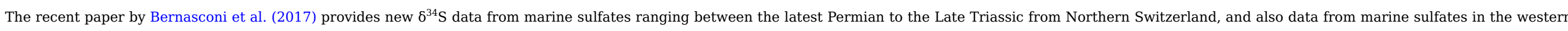

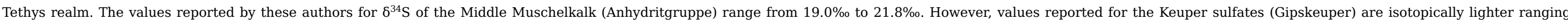
from $14.0 \%$ to $17.9 \%$ (Bernasconi et al., 2017, Supplemental data).

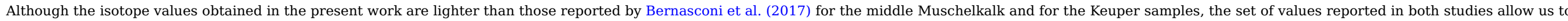

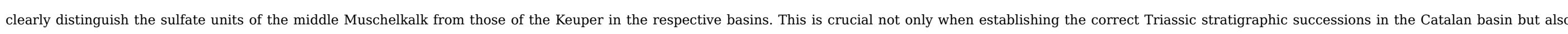
when it comes to solving structural issues as shown in works of regional geology in other Triassic basins of the Iberian peninsula (Boulouard and Viallard, 1981, in the Castillian Branch of the Iberian Ranges).

\subsection{Siliciclastic facies associated with the evaporites}

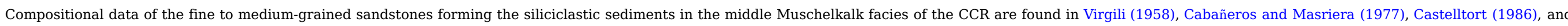

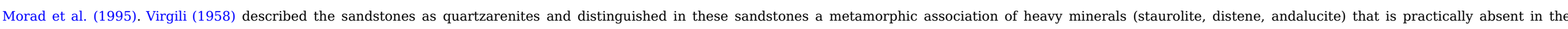

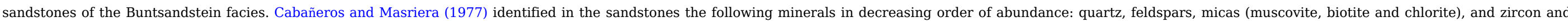

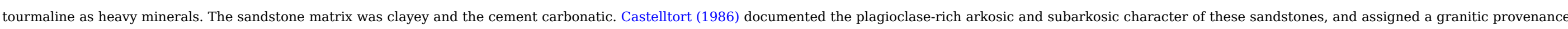

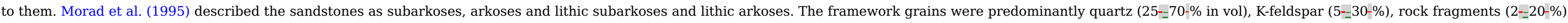
and muscovite (trace to $8 \%$ ). These authors also documented in detail many diagenetic aspects of these deposits.

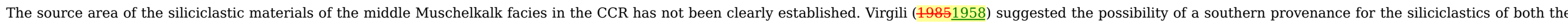

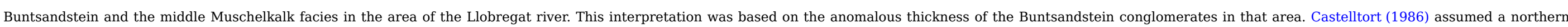
provenance (Montseny Massif), although variable in a fan of $90^{\circ}$ (NW/NE-SE/SW). Transport distances from this source were estimated in about $50 \mathrm{~km}$.

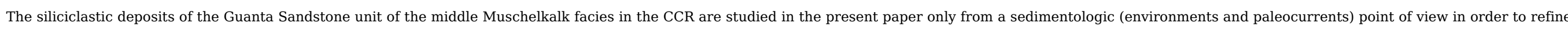

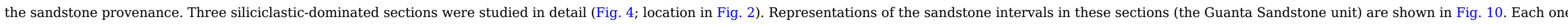

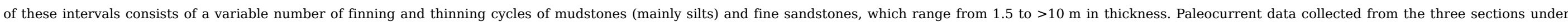

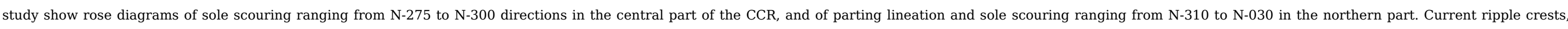

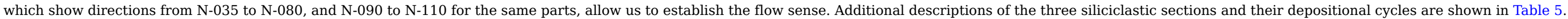




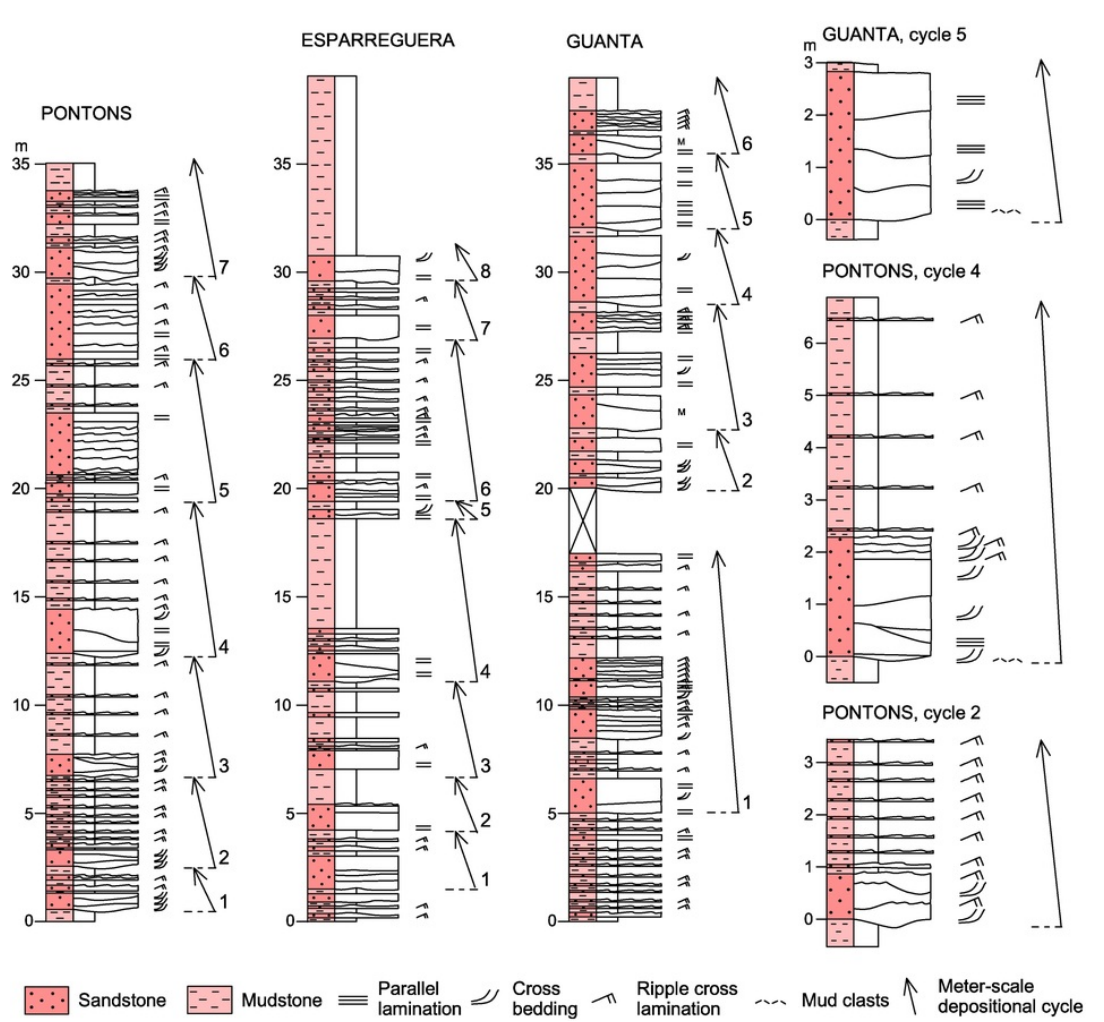

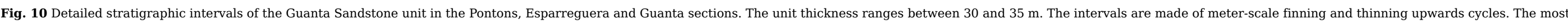

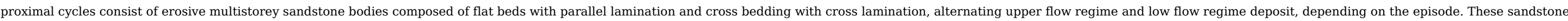

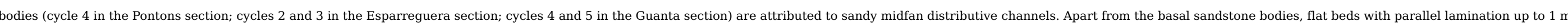

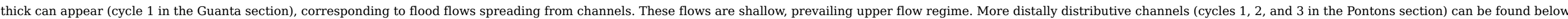
and above the most proximal cycles; these deposits are formed in low flow regime. Sections location in Fig. 2.

alt-text: Fig. 10

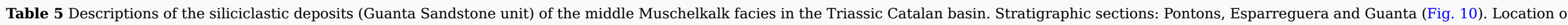
these sections in Fig. 2. DC: depositional mudstone-sandstone cycle.

\section{alt-text: Table 5}

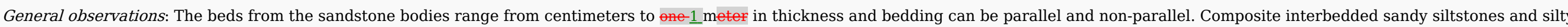
mudstones form the upper part of the cycles. Sole surfaces in the cycles are erosive and most of them are planar. Only occasionally is the sole erosion due to scouring.

\section{Pontons section (51 m thick)}

- Hydraulic regime: low and upper flow regime;

- Finning and thinning upwards cycles: there are 7 cycles, with single thickness from 1.5 to $7 \mathrm{~m}$.

- Basal sandstone bodies: these bodies are multistorey in all the cycles, combining non-parallel bedding with cross-lamination and flat bedding with parallel lamination;

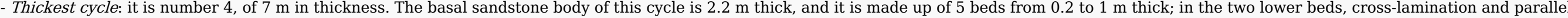

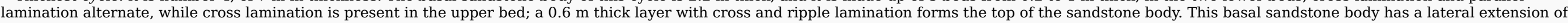




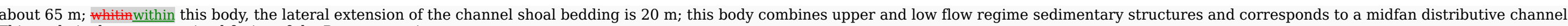
This cycle is the most proximal facies of the Pontons section

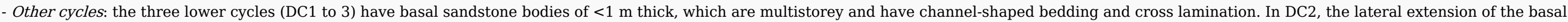

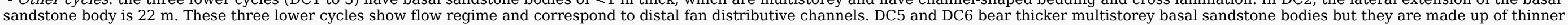

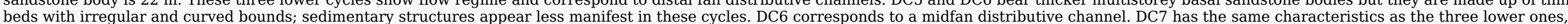
with a multistorey sandstone body of $1 \mathrm{~m}$ thick that shows lenticular bedding;

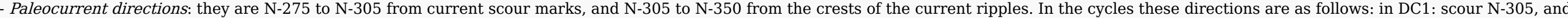
current ripples N-305/330/350; in DC2: scour N-275; in DC4: scour N-300; in DC7: scour N-285.

\section{Esparreguera section $(70 \mathrm{~m}$ thick)}

- Hydraulic regime: low and upper flow regime;

- Finning and thinning upwards cycles: there are 8 cycles, with single thickness from 2 to $8 \mathrm{~m}$.

- Thickest cycle: it is number 4, of $8 \mathrm{~m}$ in thickness;

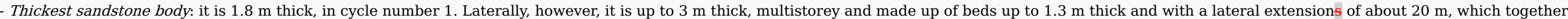

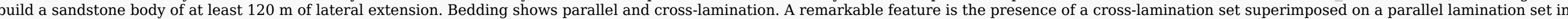
the same bed,

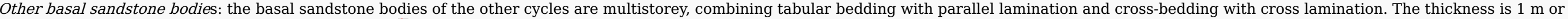

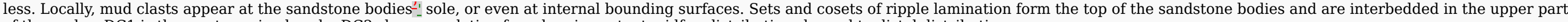
of the cycles. DC1 is the most proximal cycle. DC2 shows gradation from less important midfan distributive channel to distal distributive one

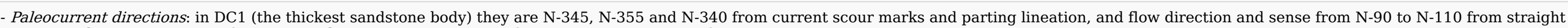
current ripples; in DC3: N-340 from parting lineations; in DC6: N-05 from scour; in DC8: N-15 from scours.

Guanta section (68 $\mathrm{m}$ thick; the base and the top of this sections do not croup out)

- Hydraulic regime: low and upper regime. This is the most proximal of the three sections studied;

- Finning and thinning upwards cycles: there are 5 cycles;

- Thickest cycle: it is number 2. Its basal sandstone body is $1.5 \mathrm{~m}$ thick, with lateral length of $30 \mathrm{~m}$

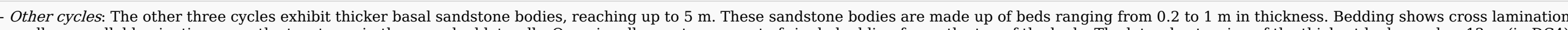

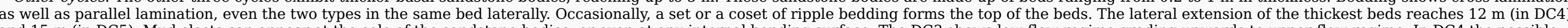

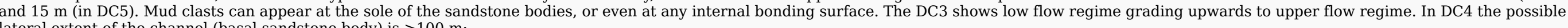
lateral extent of the channel (basal sandstone body) is $>100 \mathrm{~m}$

Paleocurrent directions: in DC2: N-335 from scour marks and N-310 from parting lineation; in DC4: N-030 from scour marks.

\subsubsection{Interpretation}

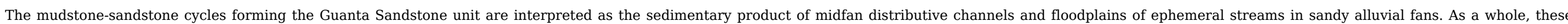

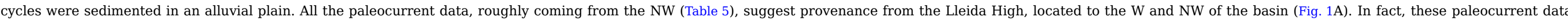
are not very different from those documented for the sandstones of the Buntsandstein facies in Marzo (1980) and in Calvet and Marzo (1994).

\subsection{Discussion}

\subsubsection{Evaporitic evolution of the basin}

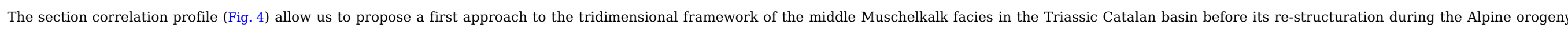

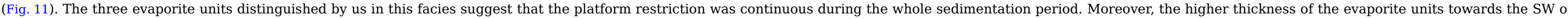
the basin together with their lateral gradation into siliciclastics towards the NE indicate that structural factors controlled the sedimentation in the basin. 


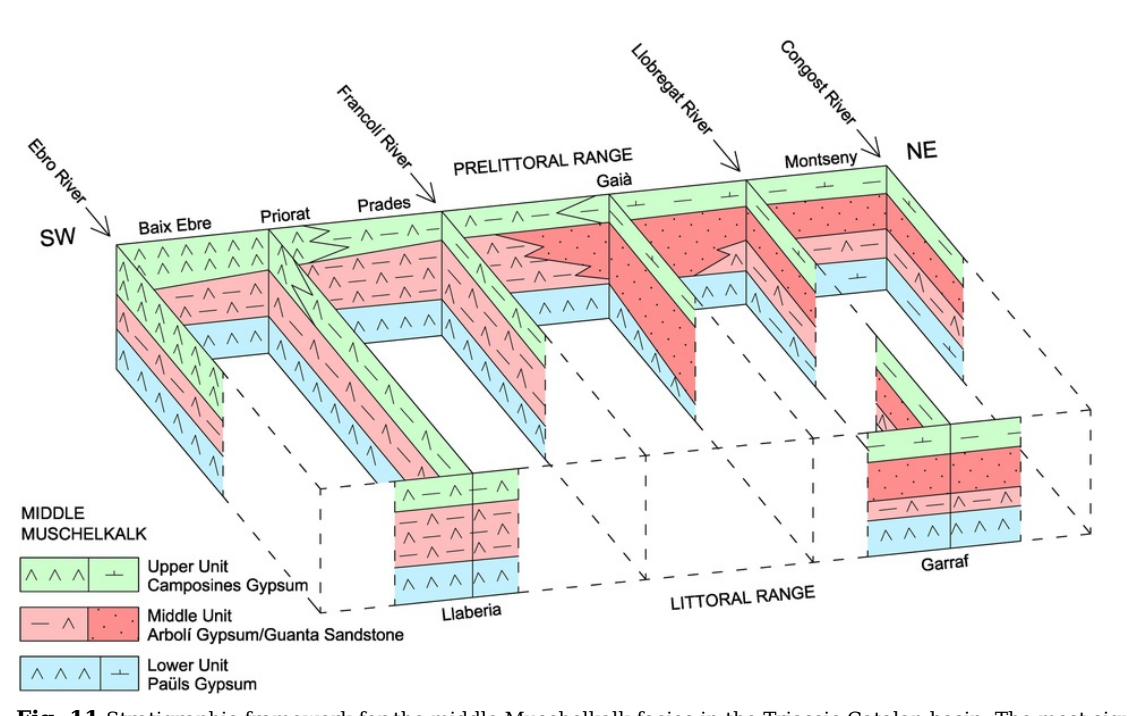

Fig. 11 Stratigraphic framework for the middle Muschelkalk facies in the Triassic Catalan basin. The most significant lateral facies changes are indicated. Scheme out of scale. alt-text: Fig. 11

\subsection{Lower Unit: transgressive sulfate lagoon}

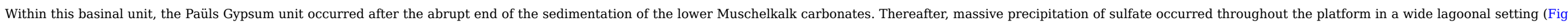

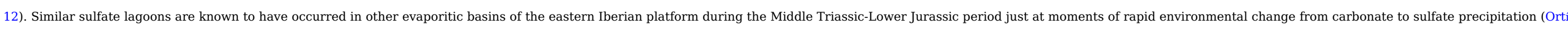

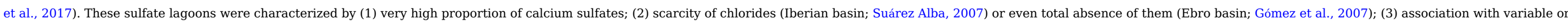

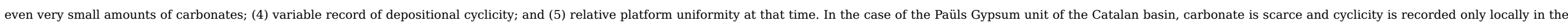
lower part of the unit. The sulfates extended throughout a uniform lagoonal basin, although mudstones were predominant in the northeastern part. 


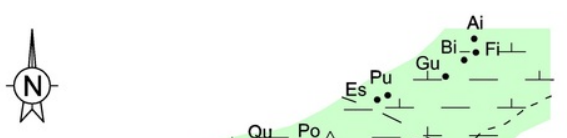

UPPER UNIT

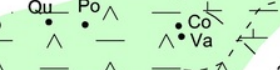

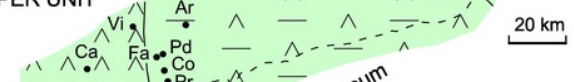

$\wedge \wedge \cdot \wedge \hat{\wedge}$

$\hat{P_{0} \wedge \wedge \wedge \wedge} \wedge \wedge$

$\mathrm{Pal}^{\circ} \bullet \wedge \wedge \hat{\wedge} \wedge$

$\wedge \wedge \wedge ' \wedge, \wedge$

$\wedge \wedge,-\wedge \wedge$

MIDDLE UNIT

Late stage

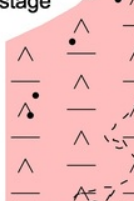

MIDDLE UNIT

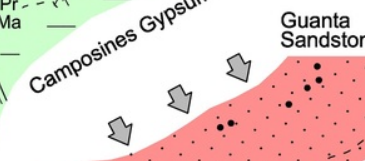

Guanta
andstone
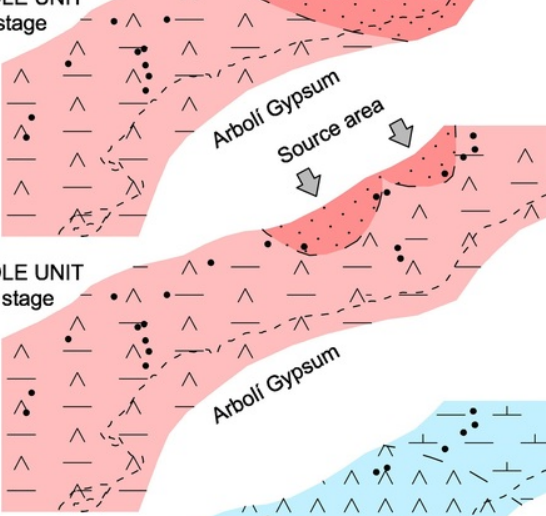

$\wedge \wedge \hat{\wedge} \wedge \wedge \hat{\wedge} \wedge \wedge \hat{\wedge} \wedge \hat{\wedge}-\Delta-\lambda$

$\wedge \wedge \bullet \wedge \hat{\imath}$

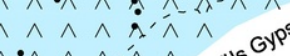

$\wedge \wedge \wedge \wedge \wedge \wedge$

$\hat{\wedge} \wedge \hat{\wedge} \hat{\hat{x}} \cdot \hat{\wedge}$

$\hat{\wedge} \wedge \hat{\wedge} \wedge-\wedge$

$\triangle$ Sulfate lagoon

$E \wedge$ Evaporitic mudflat

$\perp$ Marly mudflat

- Alluvial plain

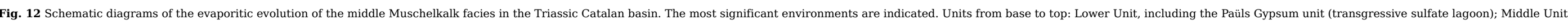

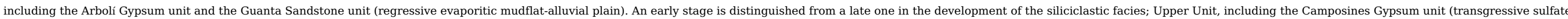
lagoon-evaporitic mudflat).

alt-text: Fig. 12

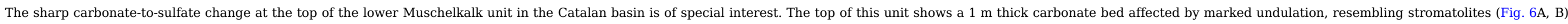

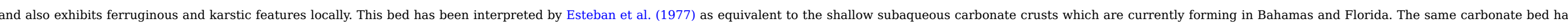

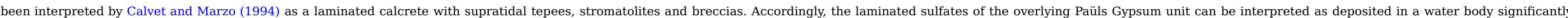

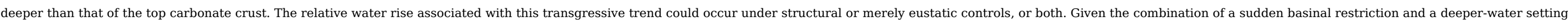
we may interpret that an extensional pulse provoked the basin confination and prevented the carbonate production in a relatively uniform platform. Intense deposition of evaporites occurred in the south of the basin.

\subsection{Middle Unit: regressive evaporitic mudflat-alluvial plain}

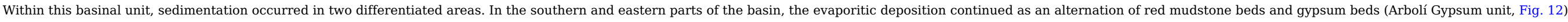




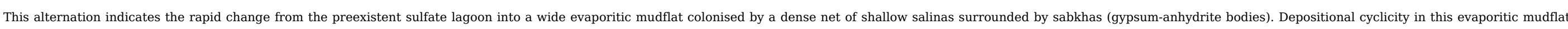

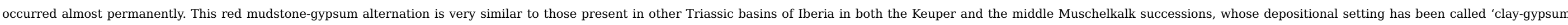
alternation salinas' in Ortí et al. (2017).

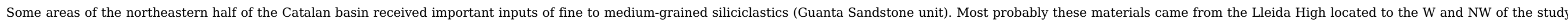

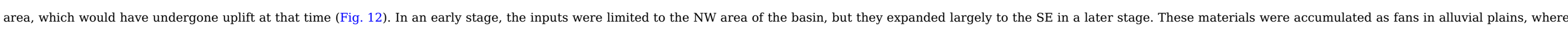

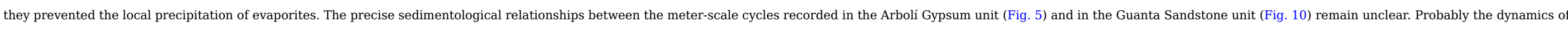
the alluvial fan systems induced shifting in the frontal and peripheral salinas, which hinders the cycle correlation between them.

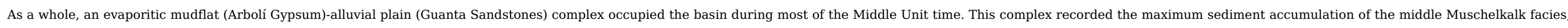

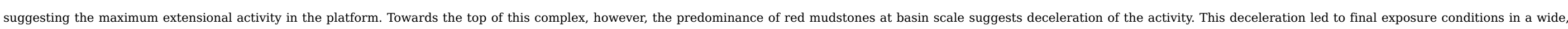
distal red mudflat. Compared to the Lower Unit, the Middle Unit represents regressive trend, progressive loss of marine influence, and lack of uniformity in the depositional environments of the basin.

\subsection{Upper Unit: transgressive sulfate lagoon-evaporitic mudflat}

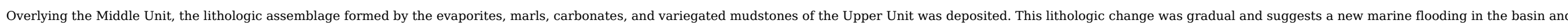

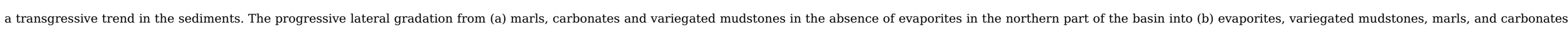

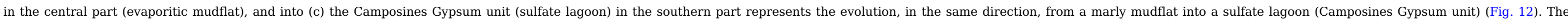

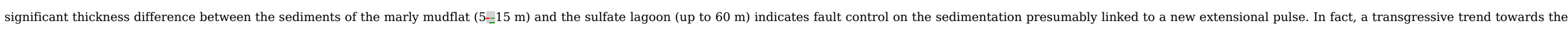
west had been already assumed by Castelltort (in Marzo and Calvet, 1985) for its upper basinal unit. This transgressive, Upper Unit graded upwards into the marine carbonates of the upper Muschelkalk.

\subsubsection{Comparison with the Triassic Maestrat basin}

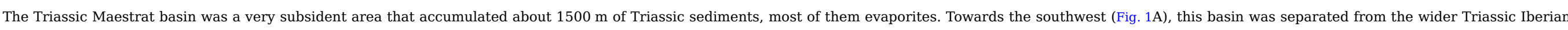
basin by the NW-SE elongated Ateca-Castellón High (Castillo Herrador, 1974). Towards the northeast, the basin was connected to the Triassic Catalan basin.

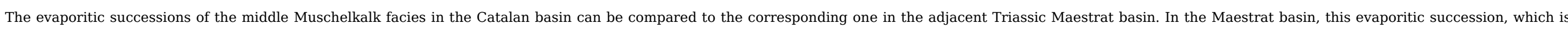

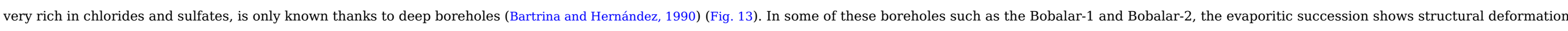

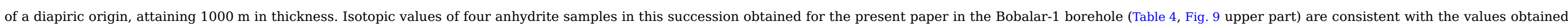
in the middle Muschelkalk sulfates of the Catalan basin. 


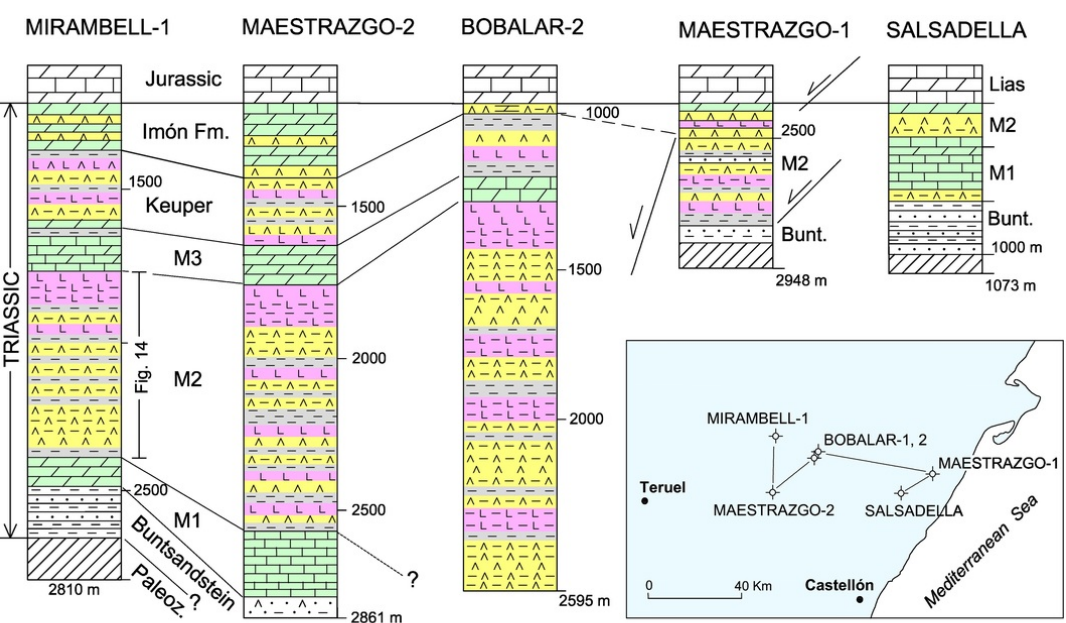

臣L Limestone F Dolostone

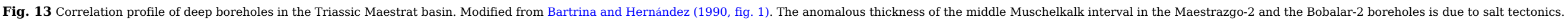
alt-text: Fig. 13

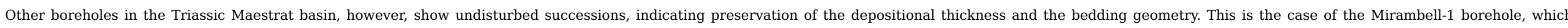

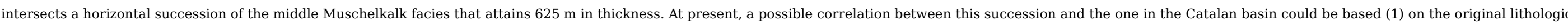

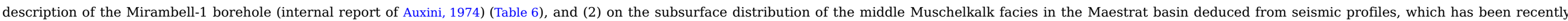
documented by Nebot and Guimerà (2016a, 2016b).

Table 6 Lithologic description for depth intervals of the Mirambell-1_deep borehole (Auxini, 1974) (no mention to the $1842^{--}-1848 \mathrm{~m}$ interval is found in the original description). alt-text: Table 6

Mirambell-1 deep borehole (Auxini, 1974)

Middle Muschelkalk:_1774--2398 m (624 m):

- 1774-_1842 m: Halite rock, translucent and bearing thicker horizons of greenish-gray claystone;

- 1848-_1889 m: Beige claystone with levels of gray claystone;

- 1901-_1938 m: Anhydrite, salt rock, and plastic gray claystone

- 1938-_2004 m: Plastic gray claystone with some levels of anhydrite and salt;

- 2004--2030 m: Salt rock with thin levels of claystone;

- 2030--2248 m: Irregular alternation of beige anhydrite, salt with clayey-anhydritic inclusions, and plastic, green-gray claystone,

- 2248--2266 m: Massive, white salt rock;

- 2266--2352 m: Hard, saliferous-anhydritic gray claystone; compact, severely recrystallized anhydrite bearing intercalations of dolomitic claystone;

- 2352-_2362 m: Slightly dolomitic, gray marls;

-2362--2378 m: Hard, recrystallized beige anhydrite with some levels of dolomitic claystone;

-2378--2392 m: Salt rock with anhydrite at the base; 


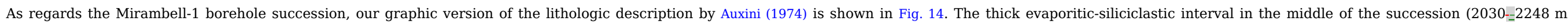

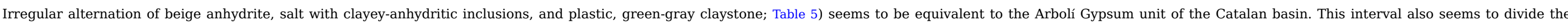

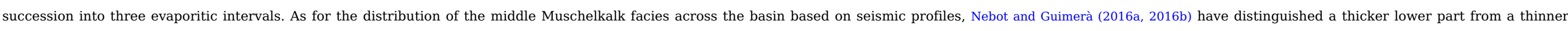

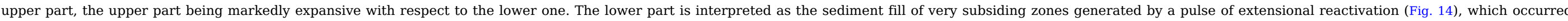

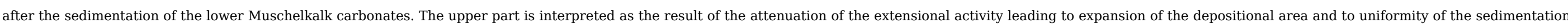
at basin scale (Nebot and Guimerà, 2016a, 2016b).

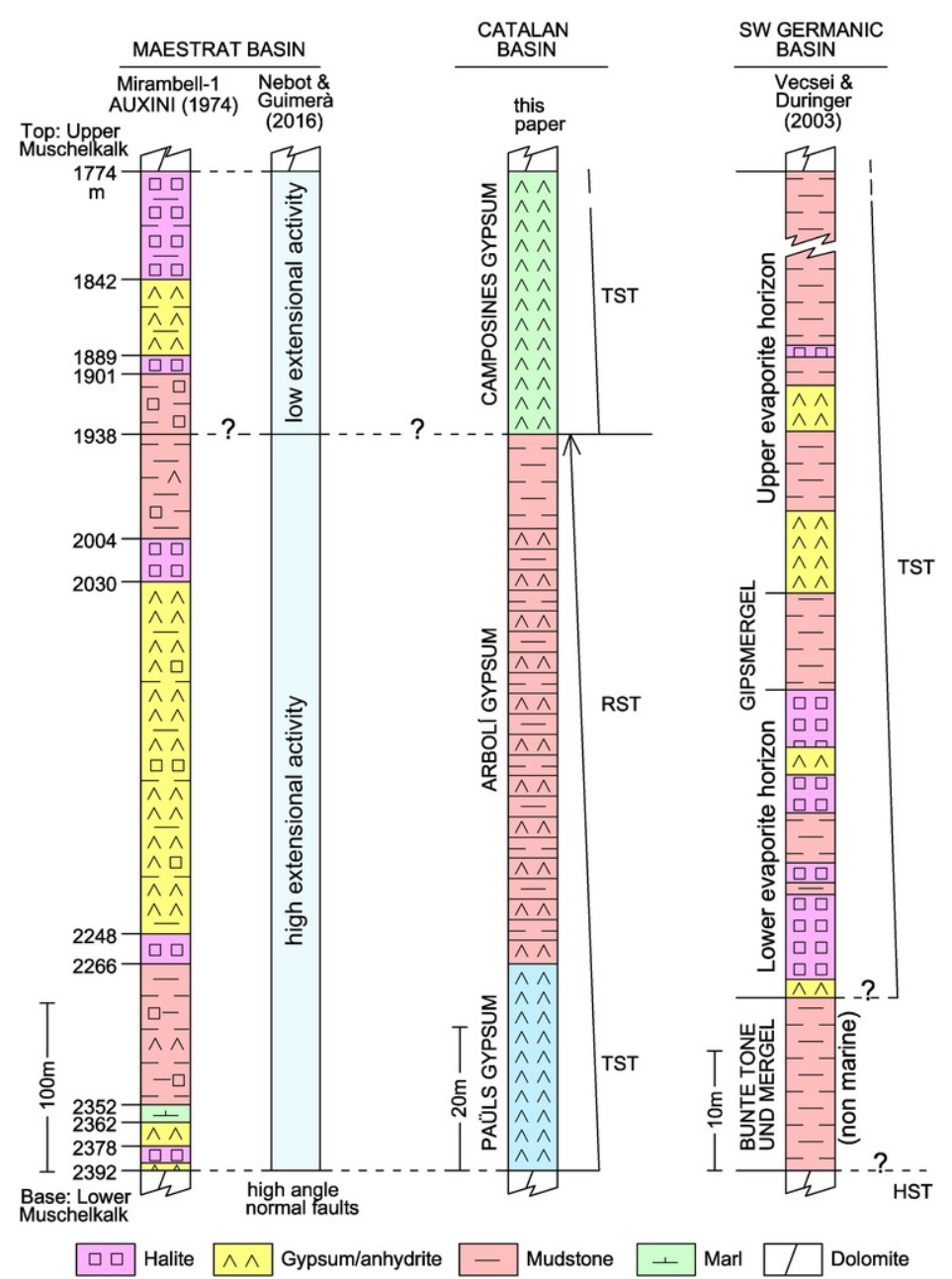

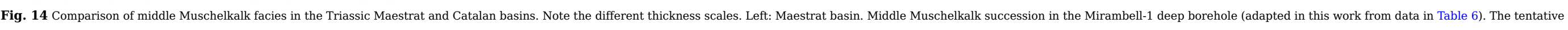

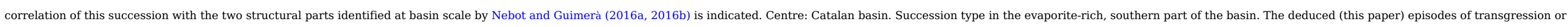

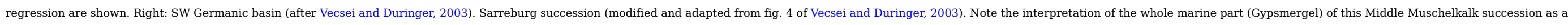
transgressive system tract. 


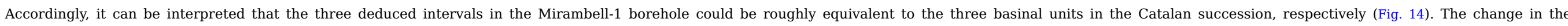

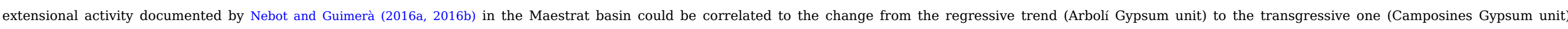
interpreted by us in the Catalan basin (Fig. 14).

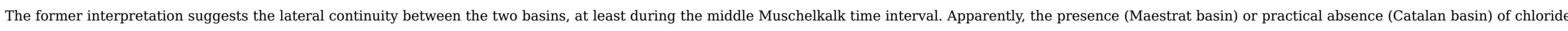

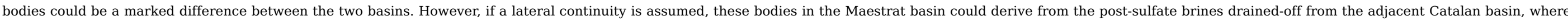
only sulfates precipitated. The higher subsidence rate in the Maestrat basin at that time would have favored this flow of heavy brines.

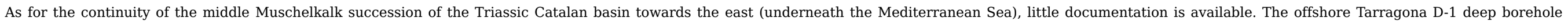

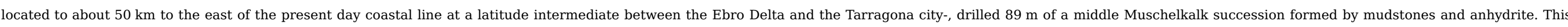

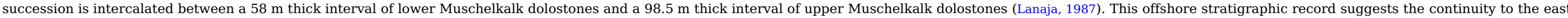
of the middle Muschelkalk evaporites.

\subsubsection{Third-order depositional sequences}

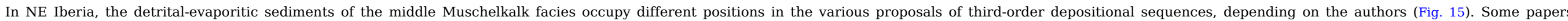

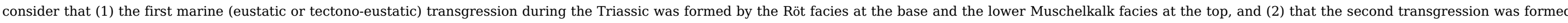

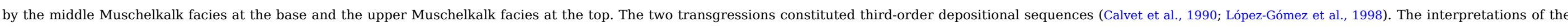

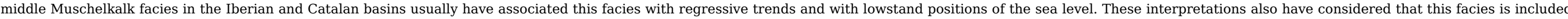

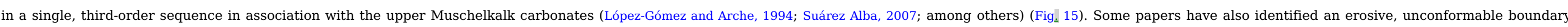

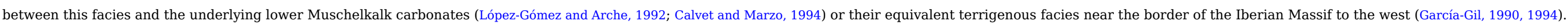

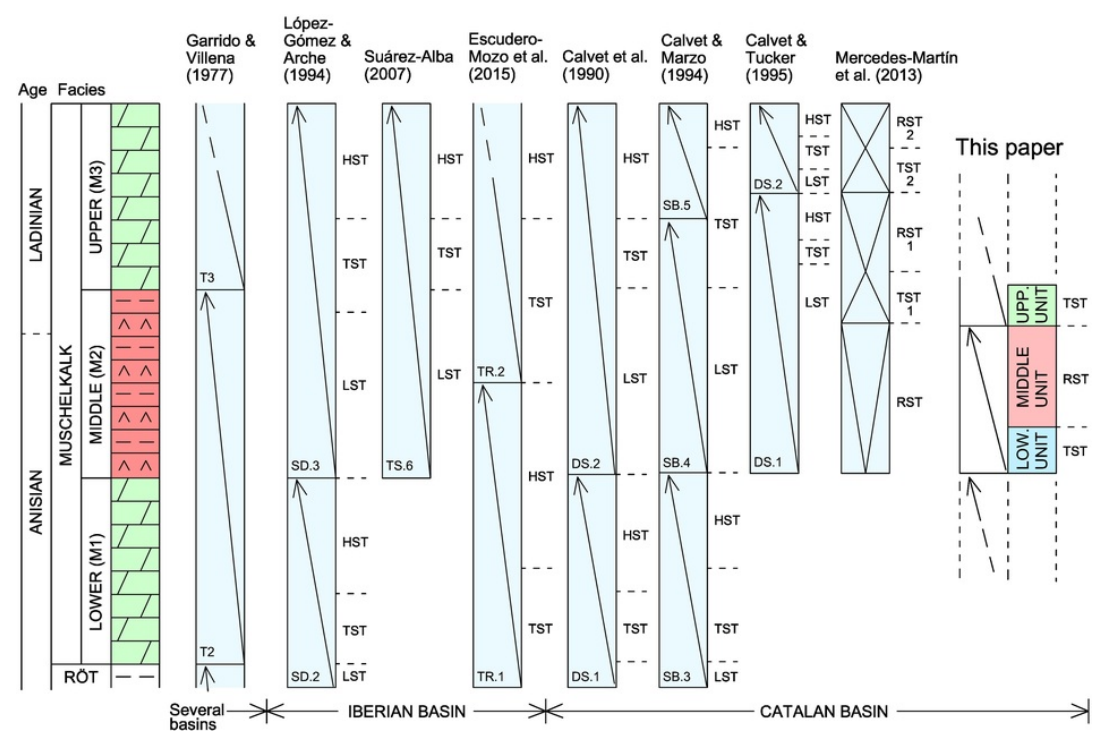

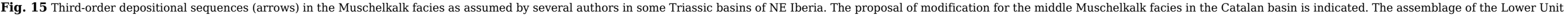
(TST) and the Middle Unit (RST) is considered to be an independent, third-order depositional sequence. 


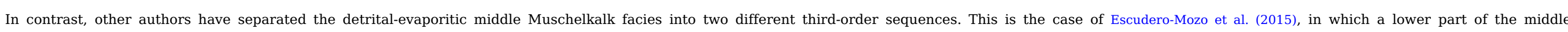

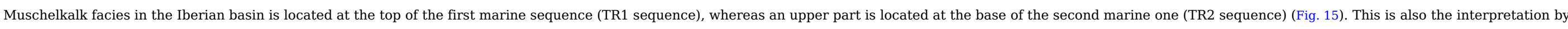

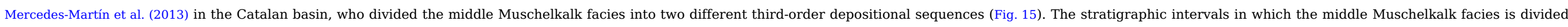
are ambiguous in these interpretations. However, the middle Muschelkalk succession in the Triassic Catalan basin might shed some light on this ambiguity.

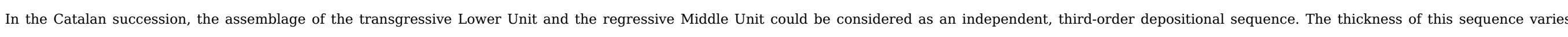

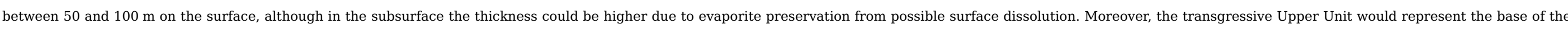

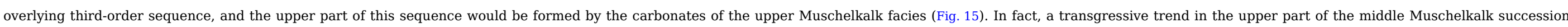
had been already assumed by Mercedes-Martín et al. (2013) for the Triassic Catalan basin (Fig. 15, TST-1).

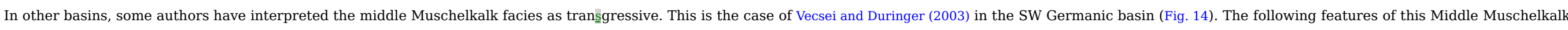

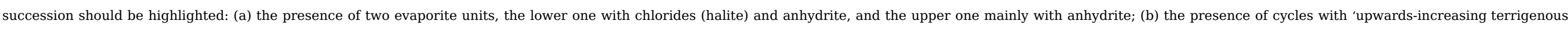

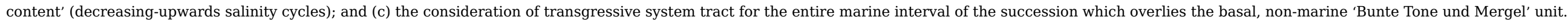

\subsection{Conclusions}

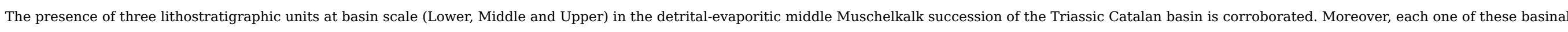

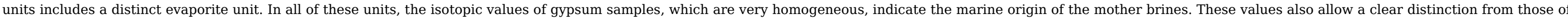
the Keuper sulfates in this basin.

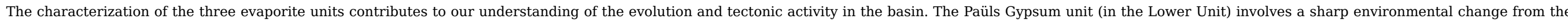

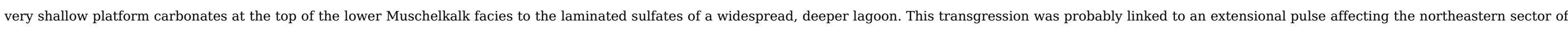
the Iberian platform during the Anisian (Middle Triassic).

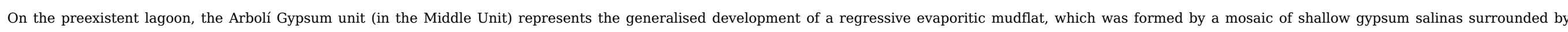

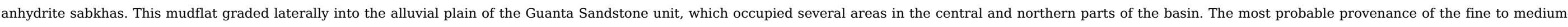
grained siliciclastics is from the Lleida High, located to the W and NW, which would have undergone uplift at that time. This provenance is useful for delineating the western boundary of the basin.

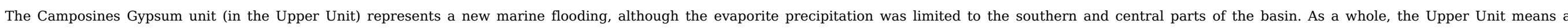

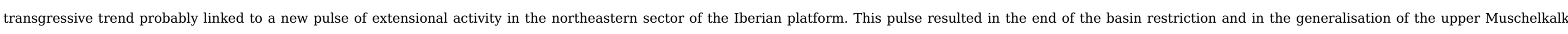
carbonates.

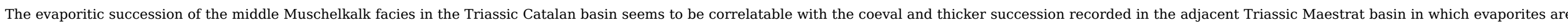
totally predominant.

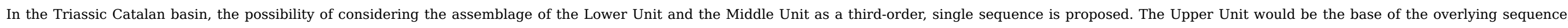
whose top would be the upper Muschelkalk carbonates.

\section{Uncited reference}

Garrido and Villena, 1977

\section{Acknowledgements}

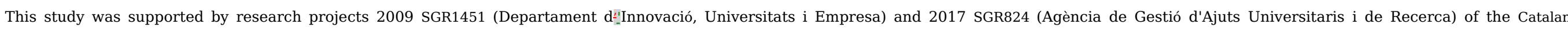
Government and CGL2015-66835-P of the Spanish Government (Ministerio de Ciencia e Innovación). Review comments by Editor Prof. Brian Jones and two anonymous reviewers improved the manuscript. 


\section{References}

Auxini, Informe final del sondeo MIRAMBELL-1. Departamento de Investigaciones Petrolíferas, Inf. 08491, In: Technical Report, 1974, Auxini; Madrid, 1-35.

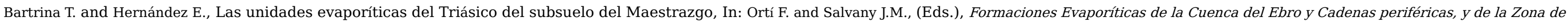
Levante, 1990, ENRESA-Universitat de Barcelona, 34-38.

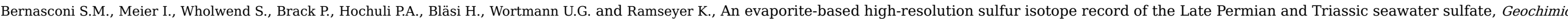
et Cosmochimica Acta 204, 2017, 331-349.

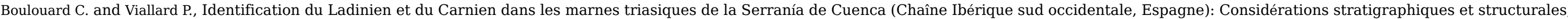
Bulletin des Centres de Recherches Exploration-Production Elf-Aquitaine 5, 1981, 31-41.

Burke W.H., Denison R.E., Hetherington E.A., Koepnick R.B., Nelson H.F. and Otto J.B., Variation of seawater ${ }^{87} \mathrm{Sr} /{ }^{86} \mathrm{Sr}$ throughout Phanerozoic time, Geology 10,1982 , $516-519$.

Cabañeros M.C. and Masriera A., Contribución al conocimiento sedimentológico del Muschelkalk medio de los Catalánides, Cuadernos de Geología Ibérica 14, 1977, 149-156.

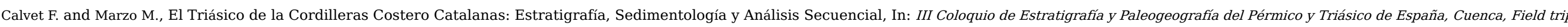
Guide, 1994, 1-53.

Calvet F. and Tucker M., Outer ramp cycles in the Upper Muschelkalk of the Catalan Basin, northeast Spain, Sedimentary Geology 57, 1988, 185-198.

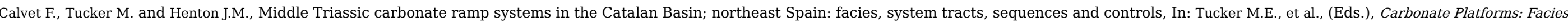
Sequences and Evolution, Special Publication of the International Association of Sedimentologists 9, 1990, Blackwell Scientific Publications; Oxford, 79-108.

Castelltort X., Estratigrafía del Muschelkalk mitjà dels Catalànids i Sedimentologia de les seves unitats detrítiques, (Graduate Thesis)1986, Universitat de Barcelona.

Castillo Herrador F., Le Trias évaporitique des basins de la Vallée de l'Ėbre et de Cuenca, Bulletin de la Société Géològique de France 16 (6), 1974, 666-675.

Claypool G.E., Holser W.T., Kaplan I.R., Sakai H. and Zak I., The age curves of sulfur and oxygen isotopes in marine sulfate and their mutual interpretation, Chemical Geology 28, 1980, 199-260.

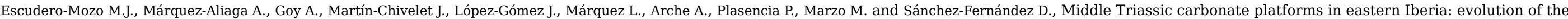
fauna and palaeogeograpic significance in the western Tethys, Palaeogeography, Palaeoclimatology, Palaeoecology 417, 2015, $236-260$.

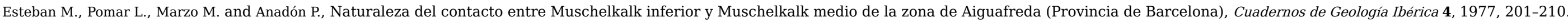

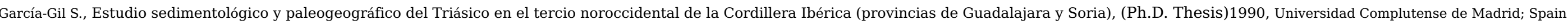
García-Gil S., El Triásico de la región de Riba de Santiuste-Arcos de Jalón, In: III Coloquio de Estratigrafía y Paleogeografía del Pérmico y Triásico de España, Cuenca, Field trip Guide, $1994,1-52$. Garrido A. and Villena J., El Trias germánico en España: paleogeografía y estudio secuencial, Cuadernos de Geología Ibérica 4, 1977, 37-56.

Gómez J.J., Goy A. and Barrón E., Events around the Triassic-Jurassic boundary in northern and eastern Spain: a review, Palaeogeography, Palaeoclimatology, Palaeoecology 244, 2007, 89-110.

Korte Ch., Kozur H.W., Bruckschen P. and Veizer J., Strontium isotope evolution of Late Permian and Triassic seawater, Geochimica et Cosmochimica Acta 67, $2003,47-62$. Lanaja J.M., Contribución de la Exploración Petrolífera al conocimiento de la Geología de España, 1987, Instituto Tecnológico GeoMinero de España; Madrid, 1-465. López-Gómez J. and Arche A., Las unidades litoestratigráficas del Pérmico y Triásico Inferior y Medio en el sector SE de la Cordillera Ibérica, Estudios Geológicos 48, 1992, 123-143.

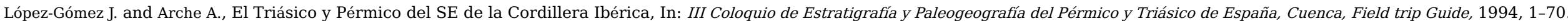




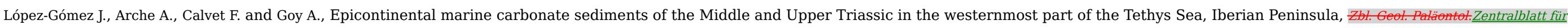
Geologie und Paläontologie 9-10, 1998, 1033-1084.

Marzo M., El Buntsandstein de los Catalánides: Estratigrafía y Procesos de Sedimentación, (Ph.D. Thesis)1980, Universitat de Barcelona; Spain.

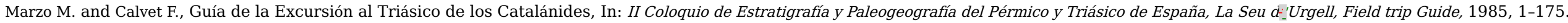

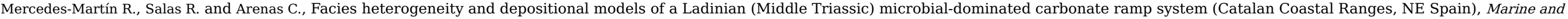
Petroleum Geology 46, 2013, 107-128.

Mitjavila J. and Martí J., El volcanismo triásico del sur de Catalunya, Revista de Investigaciones Geológicas de la Diputación Provincial de Barcelona 42 (43), 1986, 89-103.

Moore D. and Reynolds R.C., Jr., X-ray Diffraction and the Identification and Analysis of Clay Minerals, 1989, Oxford University Press; Oxford.

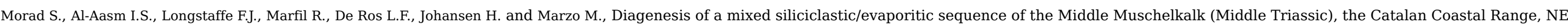
Spain, Sedimentology 42, 1995, 749-768.

Nebot M. and Guimerà J., Structure of an inverted basin from subsurface and field data: the Late Jurassic-Early Cretaceous Maestrat Basin (Iberian Chain), Geologica Acta 14, 2016a, 155-177.

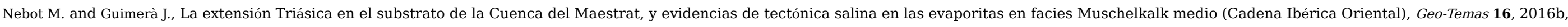
$241-244$.

Ortí F. and Bayó A., Características litoestratigráficas del Triásico medio y superior en el “Baix Ebre” (Tarragona-España), Cuadernos de Geología Ibérica 4, 1977, 223-238.

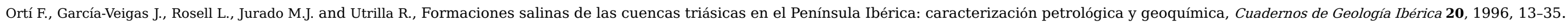

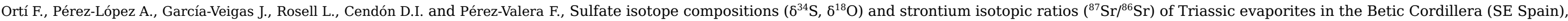
Revista de la Sociedad Geológica de España 27 (1), 2014, 79-89.

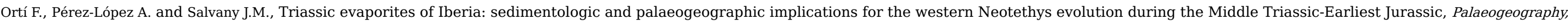
Palaeoclimatology, Palaeoecology 471, 2017, 157-180

Salvany J.M., El Keuper dels Catalànids, petrologia i sedimentologia, (Graduate Thesis)1986, Universitat de Barcelona.

Salvany J.M. and Ortí F., El Keuper de los Catalánides, Cuadernos de Geología Ibérica 11, 1987, 215-236.

Simms M.J. and Ruffel A.H., Synchroneity of elimateclimatic change and extinctions in the Late Triassic, Geology 17, 1989, 265-268.

Solé de Porta N., Calvet F. and Torrentó L., Análisis palinológico del Triásico de los Catalánides (NE España), Cuadernos de Geología Ibérica 11, 1987, $237-254$.

Song H., Tong J., Algeo T.J., Song H., Qiu H., Zhu Y., Tian L., Bates S., Lyons T.W., Luo G. and Kump L.R., Early Triassic sulfate drawdown, Geochimica et Cosmochimica Acta 128, 2014, 95-113.

Suárez Alba J., La Mancha Triassic and Lower Lias stratigraphy, a well log interpretation, Journal of Iberian Geology 33 (1), 2007, 55-78.

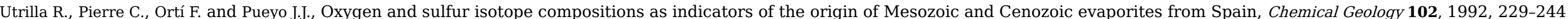

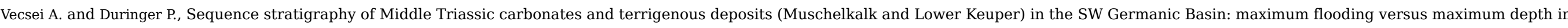
intracratonic basins, Sedimentary Geology 160, 2003, 81-105.

Virgili C., El tramo rojo intermedio del Muschelkalk de los Catalánides, Memorias y Comunicaciones Instituto Geológico Provincial de Barcelona 13, 1955, 37-78.

Virgili C., El Triásico de los Catalánides, Boletín. Instituto Geológico y Minero de España 69, 1958, 1-856. 
Virgili C., Sopeña A., Ramos A. and Hernando S., Problemas de la cronoestratigrafía del Trías de España, Cuadernos de Geología Ibérica 4, 1977 , 57-88.

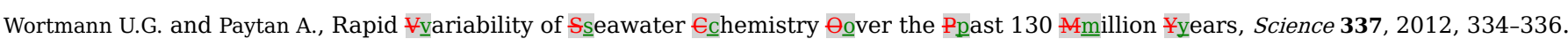

\section{Queries and Answers}

Query:

Please check the layout of Table 1 if correct.

Answer: Like in other tables, headings have been highlighted in bold character

Query:

Please check the layout of Table 3 if correct.

Answer: Yes

Query:

Please check the layout of Table 5 if correct.

Answer: Yes

Query:

Please check the layout of Table 6 if correct.

Answer: Yes

Query:

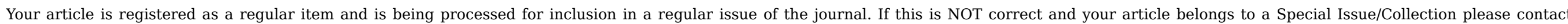
s.sankaran@elsevier.com immediately prior to returning your corrections.

Answer: Yes

Query:

Please confirm that given names and surnames have been identified correctly and are presented in the desired order, and please carefully verify the spelling of all authors' names.

Answer: Yes

Query:

The author names have been tagged as given names and surnames (surnames are highlighted in teal color). Please confirm if they have been identified correctly.

Answer: Yes

Query:

Please check the hierarchy of the section headings and confirm if correct.

Answer: Yes 
Query:

Citation "Castelltort, 1985" has not been found in the reference list. Please supply full details for this reference.

Answer: The correct citation is: Castelltort (in Marzo and Calvet, 1985). The change has been introduced.

Query:

Citation "Virgili (1985)" has not been found in the reference list. Please supply full details for this reference.

Answer: The correct citation is: Virgili (1958). This citation should appear in blue color.

Query:

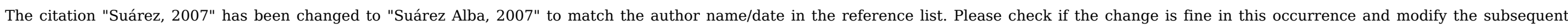
occurrences, if necessary.

Answer: The change is fine. The other occurrences have been also modified.

Query:

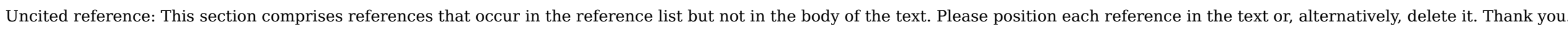
Answer: This reference appears in Fig. 15 but not in the text, We consider that this reference should be included in the references list.

Query:

Please check the page range in Ref. Korte et al., 2003.

Answer: The page range is correct. 